\title{
Individualização e processos de construção identitária na contemporaneidade: a perspectiva de François de Singly'
}

\author{
Teresa Cristina Rego" \\ José Geraldo Vinci de Moraes ${ }^{\text {III }}$
}

I- Esta entrevista foi realizada durante estágio pós-doutoral dos autores em Paris, desenvolvidos com 0 apoio da Fundação de Amparo à Pesquisa (Fapesp), a quem agradecemos. Agradecemos também à valiosa colaboração de Danilo Martuccelli, professor de sociologia da Faculté des Sciences Humaines et Sociales - Sorbonne da Université Paris Descartes (França) e também pesquisador do Cerlis (Centre de Recherche sur les Liens Sociaux). Sem sua generosidade, competência e parceria esta entrevista não teria se concretizado. Finalmente, agradecemos à Marcia Vinci de Moraes pelo excelente trabalho de tradução do texto.

II- Professora da Faculdade de Educação da Universidade de São Paulo, São Paulo, SP, Brasil. Contato: teresare@usp.br

III- Professor da Faculdade de Filosofia Letras e Ciências Humanas da Universidade de São Paulo, São Paulo, SP, Brasil.

Contato: zgeraldo@usp.br

\section{Resumo}

0 texto apresenta as reflexões de François de Singly, considerado hoje uma das figuras mais influentes da sociologia francesa, professor de sociologia da Faculté des Sciences Humaines et Sociales - Sorbonne da Université Paris Descartes (França) e também pesquisador do Cerlis (Centre de Recherche sur les Liens Sociaux), ligado ao CNRS (Centre National de la Recherche Scientifique). A solidez da argumentação de Singly, a criatividade e consistência de suas análises, a amplitude das referências bibliográficas em que se apoia, o rigor de seu trabalho empírico e, sobretudo, a atualidade dos problemas que enfrenta, representam uma criativa interlocução com todos aqueles interessados em compreender a particularidade dos processos de formação do indivíduo contemporâneo inserido num contexto híbrido de múltiplas referências identitárias. Sua busca por construir um referencial teórico e analítico capaz de integrar as dimensões micro e macrossociológicas é, sem dúvida, notável, já que pode significar um apoio efetivo para o debate contemporâneo de temas candentes nas ciências humanas e sociais.

\section{Palavras-chave}

Processos de individualização - Construção identitária Sociedade contemporânea - Vínculo social - Sociologia do indivíduo relacional. 


\title{
Individualization and processes of identity construction today: the perspective of François de Singly
}

\author{
Teresa Cristina Rego" \\ José Geraldo Vinci de Moraes"II
}

I- This interview was conducted during the authors' post-doctoral internship in Paris, with funds provided by the Foundation for Research Support (Fapesp), to whom we are grateful. We also thank the unvaluable collaboration of Danilo Martuccelli, professor of sociology at the Faculté des Sciences Humaines et Sociales - Sorbonne da Université Paris Descartes (France) and also a researcher in Cerlis (Centre de Recherche sur les Liens Sociaux). Without his generosity, expertise and partnership this interview would not be possible. Finally, we thank Marcia Vinci de Moraes for her excellent translation of the text.

II- Professora da Faculdade de Educação da Universidade de São Paulo, São Paulo, SP, Brasil. Contato: teresare@usp.br

III- Professor da Faculdade de Filosofia Letras e Ciências Humanas da Universidade de São Paulo, São Paulo, SP, Brasil.

Contato: zgeraldo@usp.br

\section{Abstract}

This paper presents reflections by François de Singly, considered today one of the most influential character in French sociology, professor of sociology at the Faculte des Sciences Humaines et Sociales - Sorbonne of the Université Paris Descartes (France) and also a researcher of Cerlis (Centre de Recherche sur les Liens Sociaux), associated with CNRS (Centre National de la Recherche Scientifique). The strength of Singly's argumentation, the creativity and consistence of his analyses, the breadth of the bibliographical references that support his views, the rigor of his empirical work and, especially, the up-to-dateness of the problems he deals with represent a creative intercommunication with all those interested in understanding the particularity of the processes of formation of the contemporary individual within a hybrid context of multiple references for identity construction. His efforts to build a theoretical and analytical framework capable of integrating micro and macro dimensions are undoubtedly remarkable as it turns out to be an effective support for today's debate about burning issues in the human and social sciences.

\section{Keywords}

Processes of individualization - Identity construction Contemporary society - Social bonds - Sociology of the relational individual. 


\section{Apresentação}

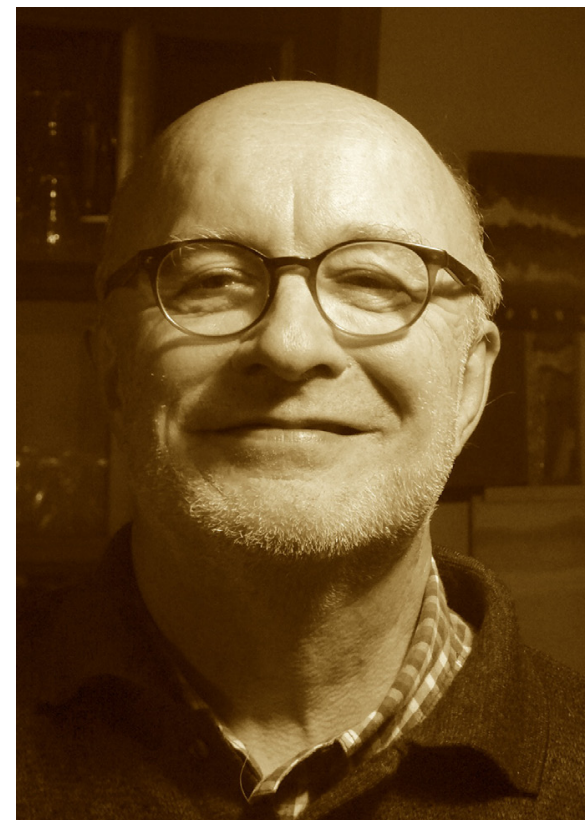

Fonte: arquivos pessoais do entrevistado.

0 texto a seguir apresenta as reflexões do sociólogo francês François de Singly, elaboradas a partir de uma entrevista concedida a Teresa Cristina Rego e a José Geraldo Vinci de Moraes, ambos da Universidade de São Paulo, em Paris entre 2015 e 2016.

As transformações (nas esferas da família, no mundo do trabalho ou nos meios de comunicação) que caracterizam a atual sociedade, bem como os efeitos desiguais dessas mudanças, instigam a adoção de novas perspectivas para as análises teóricas e os estudos empíricos. Como avaliam Peralva e Spósito (1997, p. 3): "Experimentamos hoje uma aguda consciência do novo, e da obsolescência de uma parte pelo menos das categorias através das quais várias gerações de cientistas sociais e educadores pensaram o mundo". A obra do François de Singly é marcada por essa consciência.

Considerado hoje uma das figuras mais influentes no âmbito da sociologia francesa, François Singly é professor de sociologia da Faculté des Sciences Humaines et Sociales Sorbonne da Université Paris Descartes (França).
É também pesquisador do Cerlis (Centre de Recherche sur les Liens Sociaux), ligado ao CNRS (Centre National de la Recherche Scientifique), importante instituição voltada à investigação pública francesa. As áreas de pesquisa e ensino de Singly, além da teoria sociológica em geral, se concentram na sociologia do indivíduo (processos de individualização, construção da identidade pessoal, sociedade dos indivíduos e laço social), na sociologia do adolescente, na sociologia da família e da vida privada (em relação com a segunda modernidade) e na sociologia do gênero (feminino/masculino, relação social de sexo). $\mathrm{Ou}$ seja, questões intimamente relacionadas com o mundo contemporâneo. Atualmente sua preocupação mais específica tem sido a de fazer uma inflexão analítica rumo a uma "sociologia do indivíduo relacional”, procurando exatamente ultrapassar as percepções mais tradicionais e arraigadas sobre o indivíduo. Por essa razão tem ampliado e diversificado seu campo de interesses tratando de temas conectados à produção de um mundo comum na esfera privada e de tipos de apego afetivo.

A Université Paris Descartes, à qual Singly está vinculado, é uma instituição pública de referência no contexto universitário francês e internacional, que exerce liderança acadêmica em muitos campos. Organizada em nove unidades, ela abrange áreas do conhecimento relativos às ciências humanas e à saúde. A Faculté des Sciences Humaines e Sociales Sorbonne, por sua vez, é composta por três departamentos: Departamento de Ciências da Educação, Departamento de Ciências da Linguagem e Departamento de Ciências Sociais. Apresenta uma ampla oferta de cursos de graduação e pós-graduação com reconhecido prestígio. Além de ser reconhecida pela alta qualidade de sua formação e da excelência de seu corpo docente, sua projeção na Europa e em todo o mundo decorre dos inúmeros programas de pesquisa e do intercâmbio com universidades de diversos países.

Singly está vinculado ao Cerlis, um dos laboratórios sediados no departamento de 
Ciências Sociais. 0 centro realiza pesquisas e discussões de aspectos teóricos e empíricos em torno da questão do vínculo social. 0 centro é considerado um dos principais polos universitários de investigação na França, tanto pelo número de linhas de pesquisa, como pela excelente qualidade alcançada nesse campo. Está organizado em três linhas de investigação: 1) laço social e categorização; 2) laço social e culturalização; e 3) laço social e individualização. Os estudos do professor François de Singly se concentram na terceira linha, que é coordenada por ele em colaboração com o sociólogo Danilo Martuccelli (2002, 2007). Juntos lideram pesquisas e estudos no campo daquilo que denominam "sociologia da individuação”, cujo objetivo central é traduzir fenômenos coletivos em experiências individuais e entender como diferentes processos de individuação produzem experiências individuais distintas (MARTUCCELLI; SINGLY, 2012). Martuccelli indica que seria necessário fazer da individuação e não do individualismo, e menos ainda do indivíduo (ou das figuras do sujeito), a chave destas interpretações. Para ele seria mais importante compreender como as diferentes sociedades, com seus distintos processos históricos, fabricam temporalmente seus indivíduos (MARTUCCELLI, 2010).

Nascido na França em 1948, Singly primeiramente graduou-se em psicologia e trabalhou no CNRS como psicólogo experimental. Renunciou dessa atividade em 1970, quando iniciou seu processo de formação na sociologia. Na pós-graduação, começou a se dedicar ao estudo da vida familiar e conjugal primeiramente sob a supervisão do sociólogo Jean-Claude Passeron (doutorouse em sociologia em 1973, na Universidade de Paris VIII) e, em seguida, do demógrafo Alain Girard (concluiu seu segundo doutorado em 1984, em letras e ciencias humanas, na Universidade de Paris V). Suas investigações iniciais originaram uma série de publicações e, mais tarde, novas pesquisas. Antes de ser nomeado para a Université Paris Descartes,
Singly lecionou na Universidade de Nantes (nesse período ele colaborou com Claude Thélot, então diretor regional do Institut National de la Statistique et des Études Économiques (Insee), realizando operações secundárias de pesquisas quantitativas) e Rennes 2.

Atualmente, além de membro do Haut Conseil de la Famille (conselho presidido pelo Primeiro-Ministro francês, cuja tarefa principal é elaborar subsídios e recomendações sobre a política familiar na França), François Singly preside a comissão Pour une stratégie nationale de l'enfance et de l'adolescente que visa a elaboração de estratégias para o desenvolvimento de ações unificadas junto a crianças e jovens no contexto francês.

É preciso registrar que, apesar de ser reconhecido internacionalmente, sua numerosa produção (parcialmente traduzida para diferentes idiomas), composta de aproximadamente duas dezenas de livros, um número expressivo de capítulos de livros e artigos em periódicos (como o leitor poderá constatar na relação das principais publicações de François de Singly apresentada ao final do artigo), ainda é muito pouco conhecida no Brasil e em países da América Latina. Isto é particularmente curioso, dada a importância e influência que a tradição da sociologia francófona (particularmente relacionada à educação) tem em nossos meios acadêmicos. Com exceção de alguns raros grupos de pesquisa com os quais ele vem interagindo nestes últimos anos, interessados especialmente nos seus trabalhos pioneiros no campo da sociologia da família, pode-se afirmar que suas reflexões ainda não foram suficientemente divulgadas no cenário nacional, o que justifica nosso interesse em socializar a riqueza de suas proposições.

Nesta entrevista, François de Singly analisa a individualização das relações familiares, especificamente na França, estabelecendo associações entre as mudanças da modernidade e seus efeitos na família (tema explorado no livro Sociologia da família contemporânea, um dos poucos textos de sua autoria traduzidos para o português). Uma série 
de acontecimentos, como a aceitação social do divórcio, o declínio da instituição do casamento e a baixa taxa de fecundidade, suscitaram o surgimento de novos modelos familiares, caracterizados, por sua vez, por mudanças nas relações entre os sexos e as gerações, dentre elas: controle mais intenso da natalidade, autonomia relativa da sexualidade referente à esfera conjugal, inserção massiva da mulher no mercado de trabalho, questionamento da autoridade paternal e atenção ao desenvolvimento das necessidades infantis e dos idosos. Em sua obra, Singly chama atenção para a dimensão relacional presente no processo constitutivo da identidade pessoal dos indivíduos, em que os outros significativos são, em geral e prioritariamente, o cônjuge ou o parceiro para um homem ou uma mulher, os pais para os filhos e reciprocamente. É por isso que ele defende que, no contexto da modernidade ocidental, a família, apesar das críticas legítimas dirigidas contra essa instituição, tem um papel específico, no qual todos podem idealmente ser reconhecidos, apoiados, cuidados por parentes ou por outros significativos.

Entre outros assuntos, Singly faz ponderadas reflexões sobre o tema dos adolescentes na contemporaneidade, assunto que abordou em Libres ensemble (2000), especialmente sobre as problemáticas de individualização e acesso à vida adulta e as tensões existentes entre a cultura geracional e a cultura herdada. Ele parte do pressuposto de que a adolescência é um tempo forte do processo de individualização, e que o adolescente é um indivíduo relacional, que se constrói em ligação com os outros.

Singly explora ainda um outro tema que merece ser destacado, trata-se da complexa relação entre os jovens, a escola, a família e o Estado. Na França, por exemplo, essas questões estão presentes atualmente nas discussões sobre a inserção do jovem no mundo do trabalho, no desemprego juvenil, nas diferenças entre os jovens dos banlieus e dos centros, na vida das famílias imigrantes, na "radicalidade" de seus jovens e assim por diante. No Brasil, certamente as questões são outras, mas essas relações institucionais e sociais estão presentes. No que diz respeito a esse espinhoso tema, são muito pertinentes seus comentários acerca dos traços que defınem essa relação, bem como os principais desafios a serem enfrentados na atualidade.

A solidez da argumentação de Singly, a criatividade e consistência de suas análises, a amplitude das referências bibliográfıcas em que se apoia, o rigor de seu trabalho empírico e, sobretudo, a atualidade dos problemas que enfrenta, representam uma criativa interlocução com todos aqueles interessados em compreender a particularidade dos processos de formação do indivíduo contemporâneo inserido num contexto híbrido de múltiplas referências identitárias. Sua busca por construir um referencial teórico e analítico capaz de integrar as dimensões micro e macrossociológicas é, sem dúvida, notável já que pode significar um apoio efetivo para o debate contemporâneo de temas candentes nas ciências humanas e sociais. Nesse sentido, embora assumindo perspectivas teóricas diferentes, seus esforços se somam aos de outros importantes (e mais conhecidos no Brasil) autores clássicos e contemporâneos, de diversas áreas do conhecimento; intelectuais, que de modo mais ou menos indireto, se debruçam sobre o tema da construção identitária, como: Elias (1994), Dubet (1998), Mellucci (2004), Berger e Luckmann (2012), Martuccelli (2002), Larihe (2004), Bauman (2005), Ginzburg (1987) e Sennett (2009).

Esperamos que a leitura desta entrevista contribua para a reflexão sobre os modos de vida na contemporaneidade e, principalmente, para uma compreensão mais abrangente e refinada dos problemas sociais (e humanos!) em sua complexidade. 


\section{Referências}

BAUMAN, Zygmunt. Identidade. Rio de Janeiro: Jorge Zahar, 2005.

BERGER, Peter; LUCKMANN, Thomas. La construction sociale de la realité. Paris, Armand Colin, 2012.

DUBET, François. A formação dos indivíduos: a desinstitucionalização. Revista Contemporaneidade e Educação, Salvador, v. 3 , p. 27-33, 1998.

ELIAS, Norbert. A sociedade dos indivíduos. São Paulo: Jorge Zahar, 1994.

GINZBURG, Carlo. 0 queijo e os vermes: 0 cotidiano e as idéias de um moleiro perseguido pela Inquisição. São Paulo: Cia. das Letras, 1987.

LAHIRE, Bernard. Retratos sociológicos: disposições e variações individuais. Porto Alegre: Artmed, 2004.

MARTUCCELLI, Danilo. Cambio de rumbo: la sociedad a escala del individuo. Santiago: LOM, 2007.

MARTUCCELLI, Danilo. Existe indivíduos en el Sur? Santiago de Chile: LOM, 2010.

MARTUCCELLI, Danilo. Grammaires de l'individu. Paris: Gallimard, 2002.

MARTUCCELLI, Danilo; SINGLY, François. Les sociologies de l’ individu. Paris: Armand Colin, 2009.

MELUCCI, Alberto. 0 jogo do eu: a mudança de si em uma sociedade global. São Leopoldo: Unisinos, 2004.

PERALVA, Angelina; SPÓSITO, Marilia. Editorial. Revista Brasileira de Educação, Rio de Janeiro, v. 5/6, p. 222-233, 1997.

SENNETT, Richard. 0 artífice. Rio de Janeiro: Record, 2009. 


\section{Entrevista}

Primeiramente gostaríamos de agradecer pela oportunidade de realizar esta entrevista. Embora a maior parte de suas pesquisas e reflexões faça referência à sociedade europeia e, mais particularmente, à francesa, certamente suas análises são oportunas para outras realidades sociais, como a brasileira. No Brasil, sabemos que há um público que gostaria de conhecer sua trajetória e proposições. Por essa razão, talvez fosse interessante começar com uma apresentação de seu percurso, contando um pouco de sua história de vida, de suas origens familiares, de sua infância, adolescência e de sua vida escolar.

Nasci em 1948. Até meus dezoito anos vivi em Cholet, cidade média do oeste da França, (célebre durante as guerras da Vendée contra a Revolução Francesa!). Do ponto de vista de minha trajetória pessoal, meu pai é originário de uma família nobre e endinheirada (através das alianças com a burguesia), mas, desde a morte do seu pai na guerra de 1917, sofreu uma queda livre. Ele se casou com minha mãe, da pequena burguesia. A cultura comum de meus pais foi a religião católica na sua vertente "social". Meus pais eram, sobretudo, militantes cristãos. Pouco lazer, poucos amigos. Família (somos seis filhos, sou o último) e associações. Mesmo que isso não transpareça imediatamente no meu trabalho (voltarei ao assunto), tratase do traço principal da minha família. Dois dos meus irmãos tornaram-se padres e uma irmã religiosa. Um catolicismo próximo dos mais pobres, dos meios populares, mas sem a orientação para a "luta de classes". Ousando uma aproximação, sua posição política parecia com a de Durkheim, sendo todas as coisas diferentes por outro lado. Eles tinham escolhido aderir à Ação Católica Geral dos Homens ou Mulheres, e não à Ação Católica dos Independentes (que correspondia ao movimento de seu meio social). Eles recusavam a luta de classes. Eram, por outro lado, próximos de São Francisco de Assis, pertencendo à Ordem Terceira (pessoas que queriam viver a exemplo dos frades franciscanos). Em casa, recebíamos capuchinhos e franciscanos. Francisco de Assis era um super-herói da família, e meu em particular (meu nome é testemunho disso). Quando eu era lobinho (movimento dos pequenos escoteiros), escrevi minha primeira peça encenada, era a vida de São Francisco! Escrevi uma segunda sobre o abbé Pierre, padre e deputado pelo MRP (movimento centrista cristão), que em 1954 lançou um movimento ilegal de ocupação de prédios vazios, para salvar os sem-teto do frio do inverno.

Existia, pois, uma tensão entre a posição objetiva (pai executivo numa empresa; mãe dona de casa) e sua recusa de levá-la muito a sério. Isso se traduzia da seguinte maneira: nós devíamos fazer a escola primária no ensino privado popular, sendo que, em seguida, passávamos para o liceu privado para prestar o exame do baccalauréat ${ }^{1}$ (na época, antes de 1962-63, as crianças dos meios populares não entravam normalmente direto no liceu). Eu permanecia, portanto, em Sainte-Marie de Cholet da sexta série até a terminal, escola frequentada pelos filhos de famílias da pequena e média burguesia, mas eu era escoteiro na tropa do meu bairro popular e não na do colégio/liceu. Essa tensão era visível também pelo orgulho do nosso nome (o único patrimônio simbólico que resta com a partícula "de"), mesmo que devêssemos agir como se isso não fosse nada, e ficar à vontade com pessoas de todas as origens.

Segui, portanto, os estudos clássicos (latim, grego), e passei no exame do baccalauréat em filosofia. Eu era um aluno bom, não excelente. Interessava-me por francês, literatura e história. Lembro-me de me entediar em casa (meus irmãos tinham mais dez anos

1- 0 liceu corresponde ao atual segundo ciclo do sistema de ensino francês, que equivale ao nosso ensino médio. 0 baccalauréat é o exame nacional de encerramento do nível secundário, e está dividido em três áreas: geral, tecnológico e profissional; sem ele nenhum jovem pode entrar na universidade. 
que eu e logo saíram de casa) e de ter poucos amigos. Uma das coisas que me alegrou durante a adolescência foi o surgimento de uma cultura jovem. Tive a sorte de pertencer à primeira geração que, na França, teve direito de possuir sua música. A emissão culta se denominava Saudações Companheiros. Edgar Morin teve a inteligência (os outros sociólogos duvidavam da pertinência da variável classe de idade) de compreender a aparição dos "yê-yês" (cf. Le Monde de 6-7 julho 1963, no qual ele inventa esta expressão).

Eu possuía um pequeno mundo, afastado do universo escolar e religioso, que me servia de refúgio no meu quarto. Em resumo, uma adolescência sem asperezas, sem tomada de risco, sem crise, sem relação com meninas (a não ser em sonho).

Sua primeira formação foi em psicologia, depois você acabou se interessando e se formando em sociologia. Poderia nos dizer como ocorreu essa mudança do ponto de vista pessoal e acadêmico?

"Para mim, a vida vai começar" com a faculdade, (trata-se de uma referência à minha cultura adolescente, pois trata-se do título de uma canção de Johnny Hallyday, de quem era fã). Ao contrário de alguns de meus irmãos e irmãs, não frequentei a Universidade Católica, mas uma universidade do Estado, em Nantes. E escolhi a psicologia. Isso não me trouxe problemas, porque essa orientação estava de acordo com os valores dos meus pais: a atenção aos outros. É aí que se opera a minha saída dos "trilhos familiares". Eu descubro o trabalho intelectual graças a companheiros um pouco mais velhos (que tendo feito dois anos de seminário maior, haviam clicado o botão "pause”, que se tornou definitivo), graças notadamente a Charles Suaud (que escreverá, anos depois, $A$ vocação, Minuit, 1978). E tive a oportunidade de ter um curso de introdução à sociologia, ministrado por Jean Claude Passeron. Paixão teórica. Estamos em 1966-1967. Ele nos ensina
O ofício de sociólogo (que aparece em 1968) e ele nos mostra até o segundo tomo (que jamais foi publicado!). No entanto, continuo meus estudos de psicologia (mesmo seguindo como ouvinte livre os cursos de sociologia de JCP). Obtive brilhantes resultados, principalmente em psicologia experimental, com François Richard.

0 ano de 1968 surge durante meu segundo ano de faculdade. Grandes momentos de felicidade nesse parêntese encantado. Participei do refazer o mundo de manhã à noite, sem estar engajado em qualquer movimento. $\mathrm{Na}$ volta às aulas, Richard me propõe voltar ao CNRS como auxiliar de pesquisa. Emoção e orgulho. Fim de 1969, é votada a lei sobre o ensino superior, chamada Edgar Faure (a partir do nome do primeiro ministro da educação nacional). Ela cria notadamente a Universidade de Vincennes, experimental. Jean Claude Passeron funda aí o departamento de sociologia e Jean-François Richard o de psicologia! Meu espaço geográfico se estende. Eu me inscrevo para o mestrado sempre em psicologia em Vincennes, (que se torna depois Universidade de Paris VIII, em Saint- Denis) e lá eu trabalho.

No entanto, minha vida é abalada (e continua a ser) pelo encontro com Chantal, que conheço por intermédio de um grupo de colegas, sempre na esfera católica. Ela, que viria a se tornar minha esposa, é de Nantes, e realizava na época estudos no campo das ciências econômicas. Tento convertê-la pela leitura do Ofício de sociólogo, minha bíblia da época. Richard me propõe prosseguir na tese e me tornar pesquisador. Mas os trabalhos realizados, que me satisfazem pelo rigor, me parecem "fechados". Por definição, a experiência suprime o social, controlando a situação. Não me sinto capaz de permanecer assim num mundo confinado (é assim que eu o percebo). Essa fase termina pela publicação de um artigo meu com Jean-François Richard, "Análise do conceito unidimensional na criança de cinco anos”, em Infância (1972, v. 25, n. 5, p. 349-359). Eu me demito do CNRS e me inscrevo para a tese de sociologia com Passeron. Em 
junho de 1970, mês do meu casamento, é a data do fim da psicologia e entrada na sociologia. Para ganhar a vida, torno-me "engenheiro de estudos" 2 na Universidade de Nantes, sob a direção de Michel Verret, que havia substituído Passeron na direção do departamento de sociologia. Participo de trabalhos sobre a classe operária, que, em Nantes, era o tema central da sociologia. Essa mudança de orientação não encantou meus pais, sobretudo porque estava igualmente associada à interrupção das práticas religiosas (o que não é original, pois na França, nesse momento, milhões de franceses também pararam com isso).

Talvez por causa da cultura centrista de minha mãe (minha ruptura não foi total!), escolhi como tema do doutorado de terceiro ciclo a educação moral na família. Na realidade, Jean Piaget do lado da psicologia e Emile Durkheim do lado da sociologia estudaram esse tema (mas na ordem inversa). Estamos em 1970. É a moda da pedagogia antiautoritária, com o best-seller de Alexandre Neill, Livres filhos de Summerhill (edição Maspéro) e o lançamento da Reprodução de Bourdieu e Passeron (Minuit, 1970). Eu me torno a tal ponto um apaixonado, quase dependente, que começo a escrever do mesmo jeito. Mantido em 1973, o título de minha tese tornou-se $A$ interiorização $d a$ normatividade no círculo doméstico. E para obedecer ao preceito da ruptura epistemológica, eu não quis mais utilizar as palavras comuns. Sob essa minha escrita, os pais tornaramse "agentes educadores" e os filhos "agentes educados”. Isso irritava minha mãe, e com razão.

Contrariamente ao ar antiautoritário que vigorava na época, eu insisto na autoridade pedagógica dos pais exercida de maneira suave, mascarando esse poder; ou seja, chamo a atenção para a ilusão da relação pedagógica que, no fundo, desejava mascarar a relação de forças, objetivo entre as gerações. Essa tomada de posição não contribuiu para uma boa recepção

2- Ingénieur d'études (IGE) é um cargo administrativo de caráter técnico em diversas áreas vinculado ao Estado, e sua função é acompanhar e colaborar com o pesquisador mais graduado. de meu trabalho. No entanto, com relação às teses desse período, a minha apresentava uma qualidade: ela se baseava nas pesquisas com questionários junto aos pais de diferentes meios sociais. Passeron me ensinou, com competência e paciência, a aperfeiçoar, por dezenas de vezes, o texto do questionário. Eu me tornei sensível e competente na formulação das perguntas, em ligação com a problemática teórica. Retirei desse trabalho, depois de ter efetuado outras enquetes, uma obra de metodologia: $O$ questionário, que se tornou uma referência na matéria (4. ed., 2016). Da minha tese extraí, sobretudo, um artigo para a Revista Francesa de Sociologia, "A luta conjugal pelo poder doméstico" (1976, v. 17, n. 1, p. 81-100). Nesse texto, propunha um método para observar mais tarde qual dos pais tinha conseguido impor sua norma educativa. Um dos resultados foi que nem sempre o melhor dotado de capital social, ou o pai, ganhava necessariamente. Dispor deste ou daquele capital (cultural ou de gênero) não era suficiente para prever qual dos progenitores chegaria a impor sua visão educativa.

Durante nossa formação, geralmente professores, cursos e autores nos influenciam e causam impacto que carregamos durante parte de nossa vida. Além disso, sua trajetória estudantil ocorreu nos anos 1960, período que deixou marcas profundas na juventude da época. Olhando em perspectiva para o passado, bem provavelmente os temas presentes naquela fase apontaram caminhos para suas pesquisas no futuro, como novas relações familiares, de amor, homossexualidade e assim por diante. Poderia, então, comentar um pouco sobre como essas experiências impactaram sua formação e pesquisas?

Que bela pergunta! De que maneira nossas escolhas de pesquisa e nossas orientações teóricas se articulam com nossa existência, nossa cultura e, também, como vocês tem razão em sublinhar, com a voga social e sociológica da época? Honestamente, não sei muito bem. 
Se eu permaneci, e ainda permaneço engajado de maneira dominante no domínio da família, isto, sem dúvida, não tem nada a ver com a voga reinante nos fins dos anos 60. Naquela época, o termo família estava quase banido da sociologia. Ressaltei num artigo que, nos índices muito bem feitos dos Herdeiros (Minuit, 1964) e de $A$ reprodução, não consta a palavra família, quando deveria ser destaque! Os autores deram preferência a "origem de classe", ou "meio social". A família era relegada ou aos conservadores defensores dessa instituição, como vimos durante o debate sobre o casamento para todos, ou aos psicanalistas.

Nos anos 80-90, eu quis lançar com alguns colegas uma revista centrada na sociologia da família. Estávamos de acordo a respeito de tudo, menos sobre o título. Para eles, nada de intitular a revista com esse termo. Esses colegas, aliás, não se definiam como sociólogos da família, por medo de que fossem vistos como credores de uma instituição superada a seus olhos. Se David Cooper, fundador da antipsiquiatria, não tivesse publicado um ensaio em 1972, Morte da família (Le Seuil), um sociólogo teria retomado esse título. Sem dúvida, pelo fato de ter desenvolvido uma cultura de origem na qual a família era valorizada e, também pela minha vida de família pessoal, com meus três filhos, Camille, Bertrand e Blandine, eu não via razão para renunciar a essa forma de vida privada.

Foi em outro nível que meu senso crítico passou a se exercer. Graças à leitura dos livros e artigos de Andrée Michel e de Christine Delphy, tornei-me feminista. Falando de maneira esquemática, comecei a entender que a família não era apenas um espaço de reprodução social, era também um espaço em que as relações entre os gêneros não eram apenas afetivas. É preciso lembrar, e hoje isso parece tão longe, que alguns quadros explicando a escolha do cônjuge, cruzavam a origem da mulher, fixada pela posição social de seu pai, com a posição social de seu marido. 0 sexo desaparecia para tornar mais visível que o mais importante de tudo era a classe social. Uma vez formado o casal, postulava-se que, salvo em caso de heterogamia, o casal defendia um interesse comum. 0 homem e a mulher, homógamos de um mesmo meio social, não deviam se divorciar; havia, como sublinhava Bourdieu em A distinção (Minuit, 1979), uma "harmonia dos hábitos". Não se levava em consideração a manutenção dos interesses pessoais dos dois cônjuges, o que me espantava. Isso levava a se superestimar os efeitos do pertencimento ao grupo conjugal, a esquecer a dominação masculina. Por esse motivo, eu me inscrevi na tese de Doctorat d'Etat $^{3}$ quando voltei do serviço militar em 1975, sob a direção de Alain Girard, demógrafo e sociólogo da família, pois, Passeron não podia ainda orientar um Doctorat d'Etat. Nessa ocasião, essa segunda tese era a condição que permitia exercer a função de professor em universidades e orientar pesquisas; alguns anos mais tarde, além de um doctorat, passou a se exigir também a Habilitation à diriger des recherches (habilitação para dirigir pesquisas).

0 título dessa tese de 1983, da qual publiquei uma versão condensada, Fortuna $e$ infortúnio da mulher casada, veio mais tarde. Não me lembro mais do título no momento da inscrição, mas a questão era clara: "Por que as mulheres continuam a viver para casar, a viver a dois, já que são perdedoras?". Eu quis cruzar minha leitura de Bourdieu e Passeron com minhas descobertas feministas. Isto me conduziu a tentar objetivar "o custo do casamento", graças a explorações secundárias de enquetes do Instituto Nacional da Estatística e dos Estudos Econômicos. A partir desses anos, eu me coloco no ponto de vista das mulheres, como continuei a fazer notadamente em $A$ injustiça doméstica (A. Colin, 2007) ou ainda em Separada: viver a experiência da ruptura (A. Colin, 2011).

Por quê? Primeiramente em razão da desigualdade social do gênero feminino, presente sobretudo na divisão do trabalho

3- No sistema da época, o Doctorat d'Etat era superior ao Doctorat de $3^{\circ}$ cycle. Para uma melhor compreensão dessas trajetórias e hierarquias acadêmicas, que estão sempre em mudança, o primeiro corresponderia ao nosso atual doutorado e o segundo ao mestrado. Atualmente, para se orientar pesquisas, se exige a Habilitation. 
doméstico e profissional. Em seguida, talvez pelo fato de minha posição específica na minha família de origem, nas reuniões de família, nas quais podia haver dois "clãs", o dos homens (meu pai e meus três irmãos mais velhos), que adoravam brigar oralmente e sentiam prazer em defender posições contraditórias, e o clã formado por minha mãe, minhas duas irmãs e eu, que assistia às discussões às vezes chorando (cf. "Gênero bizarro", em Jacqueline Laufer, Catherine Marry, Margaret Maruani, O trabalho do gênero, La Decouverte, 2003, p. 49-60). Isso contribuiu para desenvolver a parte "feminina" (no sentido social) de minha identidade.

Esta provavelmente deve também ser a razão de eu ter mais dificuldade para compreender a lógica masculina. Por exemplo, no meu trabalho sobre a separação, deixei de lado as entrevistas com os homens, por não conseguir formatar seus relatos. Não unicamente. Penso que o individualismo relacional, de uma individualização que se manifesta no reconhecimento pelo outro de sua identidade pessoal, está primeiramente no fato da história das mulheres. Em muitos séculos, as mulheres inventaram o amor, pediram o casamento por amor, depois o divórcio. Sua identidade se construiu na esfera privada, enquanto que os homens podiam existir de uma outra maneira, individualizando-se na esfera pública. Hoje, ainda, muitos homens vivem a dois e em família, sendo menos exigentes sobre os benefícios do reconhecimento, sendo menos reflexivos sobre sua vida privada. Vou contar um caso para esclarecer meu ponto de vista. Aconteceu comigo, quando ofereci um dos meus livros a um colega e ele me disse: "eu lhe agradeço, vou emprestá-lo hoje mesmo à minha mulher". Ele não tem tempo a perder com assuntos considerados secundários. $\mathrm{Na}$ faculdade, o curso de sociologia da família continua a ser frequentado sobretudo por jovens mulheres, sendo que o público de sociologia do trabalho é mais masculino.

Procurando sempre responder à questão colocada por vocês de maneira mais completa, tive a oportunidade, uma vez "instalado" no mundo da família, de vê-la se modificar. Nos anos 1970-80, a restauração do divórcio por mútuo consentimento (após sua supressão no início do século XIX), o fim do pátrio poder e a invenção da autoridade parental, os efeitos dos movimentos das mulheres, o desenvolvimento das famílias monoparentais e recompostas, sem esquecer a transformação da relação com a criança. A partir da metade dos anos 1990, foi colocada a questão da orientação sexual e da norma da heterossexualidade, com os debates em torno do Pacto Civil de Solidariedade (PACS, votado em 1999) e do [projeto de lei] Casamento para Todos, que abriu o casamento para todos, seja qual for a orientação sexual (votado em 2013). Eu não pude me fechar na rotina. A leitura de historiadores como Philippe Ariès, Michelle Perrot, Jean Louis Flandrin, Francis Ronsin me permitiram colocar essas mudanças na história movimentada da família na modernidade ocidental.

Já que estamos tratando de trajetória e percursos, recentemente foi realizado na Université Paris Descartes um seminário intitulado François de Singly, parcours et enjeux de recherche, cujo objetivo era exatamente discutir sua obra e trajetória ${ }^{4}$. A coordenação dos seminários foi de seu colega, professor Danilo Martuccelli, mas você esteve presente em todos os encontros, discutindo com os alunos de doutorado o seu percurso de formação e sua produção acadêmica. 0 programa dos seminários bem como as leituras selecionadas, se examinados em conjunto, desenham um interessante roteiro, que permitem compreender o modo como suas ideias foram sendo construídas e engendradas e os principais debates e desafios que você (e muitos pesquisadores da sua geração) se colocaram nas últimas décadas. Os seminários constituíram, assim, uma espécie de cartografia

4- 0 seminário foi oferecido entre os meses de setembro e dezembro de 2015, no âmbito do programa de doutorado Sciences humaines et sociales: cultures, individus, sociétés. 
de seu percurso intelectual, delineando, aos mesmo tempo, os diferentes temas mobilizados em cada época, as metodologias desenvolvidas nos diferentes estudos, a variedade de afiliações teóricas, bem como as referências bibliográficas que estiveram em voga em diferentes momentos. De certo modo, o conjunto da sua produção acaba por oferecer um fecundo painel não somente dos obstáculos e avanços da pesquisa na área da sociologia como também da própria transformação da sociedade ocidental. Você está de acordo com esta análise? 0 que você achou da experiência de participar dos seminários? Foi difícil olhar para a sua obra em perspectiva? Como se sentiu ao fazer este exercício metateórico?

Foi Danilo Martuccelli que teve essa ideia de um retorno reflexivo ao meu percurso, pois em breve me aposentarei. Aceitei com prazer, porque já havíamos feito um seminário em comum e havíamos encontrado uma maneira de fazer "duo", ele com sua grande cultura sociológica e também sua exterioridade no campo da sociologia francesa dos anos 65-80, e eu, mais sensível talvez, com a preocupação das operacionalidades das ideias. Danilo Martuccelli defende uma leitura "caridosa" dos textos, evitando misturar muito depressa um senso crítico externo, o que, confesso, acontece menos frequentemente comigo (apesar da minha cultura religiosa original!). Muito agradeço a Danilo por essa iniciativa e aos estudantes por terem entrado no jogo, enfrentando a cada vez uma leitura de um dos meus artigos.

Um dos interesses de minha trajetória não sou necessariamente o mais indicado para exprimi-la! - é que ela compreende (pelo menos em aparência) dois Singly, se é que posso me permitir esse jogo sobre meu nome de família. Um primeiro Singly na esfera de Bourdieu e Passeron, e um segundo Singly na esfera de Berger notadamente. Voltaremos ao assunto.

Os seminários dão uma visão ampla das abordagens epistemológicas e das investidas metodológicas da sua trajetória de pesquisa. A apresentação de seus trabalhos foi organizada de um modo interessante: são quatro tópicos (I. Tudo é capital; II. A identidade além dos capitais; III. 0 eu e os outros; e IV. Individualismo e individuação), que abrangem os estudos precursores e as principais inflexões presentes na construção de sua perspectiva teórica. Será que poderia fazer um balanço de toda essa produção, bem como tecer comentários sobre cada um destes tópicos (temas estudados, momentos cruciais, dificuldades, avanços, rupturas, desdobramentos ou transições). Poderia situar alguns trabalhos nesses marcos?

Penso que a caracterização de Ulrich Beck, Anthony Giddens e Scott Lash da modernidade avançada por um forte grau de reflexividade é largamente superestimada. Se é verdade que as crises, institucionais ou pessoais, conduzem a esta atitude, nos tempos menos conturbados da vida ordinária, o que conta, antes de mais nada, é manter um certo ritmo. A aceleração do tempo analisada por Harmut Rosa é compatível com a reflexibilidade permanente? Duvido. Por razões cujos fundamentos deveriam ser estudados, durante anos eu quis antes de tudo produzir, acumular pesquisas. Gracejando (um pouco), digo que uma das minhas motivações era ver meu nome na capa de um livro ou na autoria de um artigo. Não seria uma maneira pessoal de valorizar o capital simbólico da família, de me afirmar enquanto herdeiro? Nas sociedades tradicionais, nas famílias com patrimônio, o efeito de posição é importante e somente são valorizados o filho e a filha mais velha. Tirei proveito da modernidade e do primado do capital escolar, retomando os termos de Bourdieu, para poder assumir o meu lugar e fazer esquecer o "pequeno caçula".

0 que o seminário propôs é, portanto, uma reconstrução a posteriori de meu percurso, uma maneira de prestar conta do meu trabalho de pesquisa. Para começar, como já sublinhei, eu cedi ao charme intelectual de Jean Claude 
Passeron, de seu pensamento (em 1966-67, Bourdieu e Passeron ainda formam um casal intelectual). Às vezes me digo que se eu tivesse feito um curso com outro grande intelectual, eu teria realizado uma outra trajetória. Tive sorte porque aprendi, antes de tudo, a construir objetos, isto é, a romper com a divisão do trabalho entre o "alto", o mundo das teorias, e o "baixo", o universo das técnicas e dos métodos. Na Sorbonne, nos anos 60, tínhamos de um lado Raymond Aron e do outro Jean Stoezel (promotor de sondagens de opinião). Poder-se-ia acreditar que $O$ ofício de sociólogo e a crescente reputação de Bourdieu iriam tornar obsoleta essa divisão do trabalho, no entanto ela permanece a referência. Observo na minha universidade, herdeira da Sorbonne, a manutenção dessa clivagem. Desde a sua entrada no primeiro ano, os alunos têm cursos de teoria, e por outro lado, fazem trabalhos dirigidos de metodologia durante os quais realizam exercícios, desconectados das teorias que descobrirão mais tarde. Esquematizando, por um lado eles têm direito aos grandes pais, Durkheim, Weber e Marx, e por outro, são livres para escolher na atualidade um problema, um fato social.

Esta entrevista não tem por objetivo propor uma reforma do ensino da sociologia, mesmo que eu tenha um grande interesse nisso, como vocês podem compreender! Por essa razão, juntamente com dois colegas, Olivier Martin e Christophe Giraud, nós propusemos um novo manual de sociologia, desejando demonstrar que é possível aprender esta disciplina de maneira mais pragmática e conforme a perspectiva aberta por $O$ ofício de sociólogo, prolongada por Passeron em $O$ raciocínio sociológico e em seus textos publicados em Enquête.

Para me lançar na tese de Estado em 1974-1975, três artigos me serviram de suporte principal. Dois de Bourdieu - "As estratégias matrimoniais no sistema de reprodução"(Anais, 1972, v. 27, n. 4, p. 1105-1127) e "Futuro de classe e causalidade do provável”, Revista Francesa de Sociologia (1974, v. 15, n. 1, p.
3-42) - e um de Delphy, "Casamento e divórcio: impasse de face dupla”, Os Tempos modernos, 1974, n. 333-334, p. 1815-1829.

Tentei operacionalizar conjuntamente essas duas perspectivas com uma série de quadros estatísticos originais. Primeiramente observei as diferenças de rendimento do diploma no mercado de trabalho de acordo com gênero, estado matrimonial e situação familiar. Isto foi publicado em Economia e Estatística, em 1982 (n. 142, p. 7-20), graças ao apoio da redatora-chefe da revista do Insee, sob o título "Casamento, dote escolar e posição social", que chocou o diretor geral pelo fato de medir um custo do casamento e pela demonstração da desvalorização relativa do valor social das mulheres dentro da vida familiar. Em segundo lugar, comparei para as mulheres que se casam de novo, a posição social de seus dois cônjuges. Em "O segundo marido" (População, 1983, v. 34, n. 1, p. 9-28), para minha grande surpresa, o nível social dos segundos maridos, frequentemente, é equivalente ao dos primeiros. Portanto, as mulheres não conhecem uma desvalorização no mercado matrimonial, senão elas não poderiam recomeçar desta forma. Isto me permitiu compreender como as mulheres, quando entram na vida conjugal, pelo fato da divisão do trabalho entre os gêneros, podem divorciarse sob a condição de estabelecer uma nova aliança. Exprimindo-me de modo esquemático, elas são prisioneiras do casamento. Elas são dependentes dessa instituição. A queda do nível de recursos econômicos das mulheres, chefes de família monoparental ilustra esse mecanismo. 0 custo do divórcio ou da separação registra apenas o custo do casamento, pago para uma parte mais tarde.

Para a primeira sessão do seminário nomeado "Tudo é capital”, um dos textos selecionados era "As manobras de sedução: uma análise dos pequenos anúncios matrimoniais" (Revista Francesa de Sociologia, 1984, v. 25, n. 4, p. 523-559). Eu tinha preparado uma amostra de pequenos anúncios publicados na revista $O$ caçador francês. Após ensaios e erros, codifiquei 
ao mesmo tempo a apresentação de si e o pedido matrimonial. A presunção teórica era a de que a pessoa procurava obter um bom rendimento dos recursos que podia anunciar. As palavras eram codificadas duas vezes: a presença ou não desta ou daquela dimensão e, em seguida, uma forma de excelência se o termo indicava um nível "superior". Tudo podia se tornar capital. Eu distinguia três tipos: o capital econômico, o capital estético e o capital moral. A análise estatística me permitia analisar, segundo o gênero, a estrutura da oferta e a da procura a fim de ver as representações da troca desejada. Os homens desejavam trocar seu eventual capital econômico por um capital estético feminino, e as mulheres desejavam o contrário. Isto permite demonstrar que o conceito de homogamia é ambíguo, porque, insistindo na equivalência dos capitais, ele apaga as diferenças de gênero. 0 montante do capital pode ser comparável, sem que isto signifique que os capitais dos homens e das mulheres sejam os mesmos. Toda perspectiva esclarecendo um ponto de vista tende a tornar invisível as outras dimensões. Não há, ao contrário das pretensões de cada um, nenhuma teoria geral que possa dar conta da totalidade da realidade social.

Mas, se para mim este artigo permanece importante, além de sua metodologia, é porque ele marca o ponto culminante de minha adesão à perspectiva "bourdieusienne" de um indivíduo inteiramente governado pelos seus interesses e pelo rendimento dos seus capitais, inclusive nas práticas de aparência mais desinteressadas. Para Bourdieu, "introduzindo a noção de capital simbólico (e de proveito simbólico), de alguma maneira o questionamento da pergunta ingênua é radicalizado: as ações mais santas poderão sempre ser suspeitas... de serem inspiradas pela busca do lucro simbólico de santidade ou celebridade" (Razões práticas, Seuil, 1994, p. 161). Por este motivo codifiquei as qualidades dos pequenos anúncios como expressão do capital moral. Até onde isso é pertinente? Com que direito o sociólogo pode descobrir as "verdadeiras" razões inconscientes dos comportamentos? Comecei a ter dúvidas.
E, progressivamente, uma inflexão se produziu nos meus trabalhos. É o tema da segunda sequência do percurso: "A identidade, além dos capitais”. Isto não significa que os capitais e as estratégias não existem e que constituem, por sua vez, uma ilusão! Não, trata-se de pensar que o mundo social não é unidimensional, que o conjunto dos comportamentos só teria sentido na busca por um rendimento dos capitais postos em jogo. Uma certa vulgata sociológica pensa demonstrar a validade da existência da disciplina revelando que, atrás do amor, o verdadeiro mecanismo é o da única busca do lucro sob todas as formas. Nessa ótica, o amor é um obstáculo epistemológico, mascarando o jogo sério da defesa dos interesses. Eu me lembro que durante minhas conferências que se seguiram à publicação de Fortuna e infortúnio da mulher casada (Presses Universitaires de France, 1987), quase todas as mulheres que me faziam perguntas partiam de sua experiência de separação. Eu me perguntava, então, se era preciso que o amor desaparecesse para que a verdade social da vida conjugal se tornasse visível à consciência. Por que seria preciso que o sociólogo propusesse uma visão do mundo desencantado? Por que pensar que o amor só teria por função autorizar a dominação masculina na fusão dos sentimentos? Eu li num texto feminista que um marido que bate na mulher tem pelo menos o mérito de tornar visível essa dominação, enquanto que um homem que a beija o faz, conscientemente ou não, para aproveitar dentro do conforto doméstico dos serviços gratuitos fornecidos por sua esposa. Após ter aderido a uma tal concepção sobre as relações simbólicas cuja função é mascarar as relações reais de força, notadamente em minha tese do terceiro ciclo (algum traço disso pode ser encontrado em um dos meus artigos), a dúvida nasceu em mim, recusando que o mundo social seja redutivel a uma única dominação (seja sob qualquer forma). Foi durante os Encontros Anuais sobre a Família que organizei nos anos 1990, que indiquei publicamente essa inflexão (publicada em seguida em $O$ Debate, 
1990, n. 61 p. 142-154, “0 homem dual: razão utilitária, razão humanitária”). Isso me levava a buscar uma diversidade de desafios nessa ou naquela prática, em tal ou qual compromisso. Para tomar um exemplo em sociologia da educação, para Bourdieu e Passeron, a função da escola é, antes de tudo, a de contribuir para a reprodução das desigualdades sociais por meio do reconhecimento das desigualdades escolares. Joffre Dumazedier tinha razão em questionar uma outra utilidade do saber adquirido na escola ou em qualquer outro lugar, a de ser também um suporte para a emancipação do indivíduo.

Uma segunda ilustração esboçada pelo próprio Jean-Claude Passeron em "O olho e seus mestres: fábula sobre os prazeres e os saberes da pintura”, posfácio a um catálogo de exposição, Os belos camponeses pintados (Museu de Belas Artes de Marselha, 1990, p. 99-123). Ao contrário de $O$ amor pela arte (Bourdieu e Dardel, Minuit, 1966), a recepção da pintura não remete apenas ao proveito da distinção. Outros prazeres ou saberes podem ser apreendidos pelo olhar diante dos quadros. Demonstrar que quanto mais cresce o nível do diploma mais aumentam as chances de frequentar os museus, não prova absolutamente que alguns dos que param diante de um quadro não sintam uma emoção, ou qualquer outra coisa. Passeron escreve também sobre a leitura, essa competência abre para "uma atividade recriadora dos objetos consumidos e autotransformadora do consumidor" (O raciocínio sociológico, 1991, Nathan, p. 338). Nos meus trabalhos sobre a leitura tentei demonstrar que essa prática, útil para o sucesso escolar, podia também fornecer os contornos do mundo imaginário, no qual uma mulher ou um homem pode querer viver, por um lado, para esquecer, mas também para saber que emoções ele sente colocando-se no lugar de outra pessoa.

Uma vez colocada, essa afırmação não é fácil de operacionalizar. Na verdade, a enquete estatística constrói facilmente uma relação entre as características sociais e esta ou aquela prática. Mas o jogo dessas diferenças sociais faz esquecer outras alternativas que podem ser transversais. Por exemplo, uma enquete pode demonstrar que cães e gatos variam segundo a posição social de seus proprietários, mas ela não explicita para que serve um cão ou um gato, além das clivagens de raça. Voltando à escolha do cônjuge, encontrar um companheiro ou companheira leva aos capitais possuídos e ao estado do mercado, mas nada indica que os únicos critérios de seleção sejam apenas aqueles que essa sociologia comporta. Na vida cotidiana, um parceiro vai mais além do que provar seu valor social.

Para mim é um desafio revelar, para retomar o título de um clássico, “a dimensão oculta” (Edward Halll, Seuil, 1971), mascarada pela pesquisa, útil, mas limitada, das apropriações diferenciais. $\mathrm{Na}$ verdade, essa preocupação tende a fazer desaparecer também os elementos comuns. Talvez ouvir as valsas de Strauss seja uma prática pouco legítima (segundo os dados de $A$ distinção), mas isso não diz nada sobre o que as mulheres e os homens do meio popular sentem ao ouvi-las. Talvez tenham emoções semelhantes às das pessoas da classe média ou superior, ouvindo música clássica mais legítima?

A enquete por questionário revela diferenças e esconde o comum. Por exemplo, os adolescentes dos meios populares não ouvem a mesma música jovem que os de outros meios, no entanto, tanto uma como a outra possui uma função comum, a afırmação generacional. É o que desejei estudar com as conversas compreensivas nos Les adonaissants (A. Colin, 2006). As formas dessa busca de si mesmo variam segundo as categorias clássicas, mas servem de suporte a uma afirmação idêntica de emancipação, a uma vontade de não ser confundido com o status de "filho de" ou "filha de". A não similitude dos recursos culturais de que cada um dispõe em função de sua origem social não impede de ter um objetivo comum.

A segunda inflexão que minha trajetória intelectual conheceu (e que compõe o terceiro 
momento do seminário intitulado $O \mathrm{eu}$ e os outros) se produziu durante os três anos em que fui professor na Universidade de Rennes (1986-1989). A leitura de A construção social da realidade, de Peter Berger e Thomas Luckmann, e sobretudo o artigo "O casamento e a construção social da realidade" (de Peter Berger e Hans Kellner, que republiquei no número especial 102 de Dialogues, de 1988) me ajudaram a adotar uma outra perspectiva das relações conjugais. Graças à conversação, os cônjuges validam reciprocamente (pelo menos idealmente) suas experiências. 0 "eu" torna-se por um lado, "conjugal”, e é assim consolidado. 0 indivíduo constrói-se de forma relacional, inclusive na idade adulta, como sublinha Charles Taylor em As Fontes do eu (Seuil, 1998): "A descoberta da minha própria identidade não significa que eu a elaboro no isolamento, mas negocio pelo diálogo, parcialmente exterior, parcialmente interior com os outros. Minha própria identidade depende vitalmente de minhas relações dialógicas com os outros". Em Le Soi, le couple et la famille (Nathan, 1996), e igualmente em Sociologia da familia contemporânea (Nathan, 1993; A. Colin, 2014), desenvolvi a noção de individualismo-relação. Eu me apoiei, para elaborar meu modelo, na peça de Georges Bernard Shaw, Pygmaleão (1914), em que o professor ajuda Elisa a realizar seu projeto pessoal.

Se o homem ou a mulher tem necessidade do próximo para saber quem ele ou ela é, a fim de formalizar suas experiências, é sinal de certa independência, que, portanto, deve ser compatível com a exigência contemporânea de que cada um conduza sua vida de maneira autônoma. Le Soi, le couple et la famille insiste na primeira demanda, Livres juntos (Nathan, 2000), na segunda injunção. A regra para tornar conciliáveis essas duas dimensões é difícil. Dessa forma, as mulheres pedem, ao mesmo tempo, atenção por parte do seu companheiro, uma escuta que elas consideram insuficiente e a possibilidade de ter domínios reservados, um jardim secreto e, se possível, "um lugar só para si mesma”, retomando o título de uma conferência de Virginia Woolf (1929). Os casais se distinguem de acordo com o tipo de ponderação entre as duas demandas, alguns insistem antes de tudo na autonomia e na vida pessoal, próxima do modelo da relação pura esboçada por Giddens em A transformação da intimidade (Rouergue, 2004), outros preferem não hierarquizar entre autonomia e dependência afetiva. Alguns acentuam a intimidade pessoal, outros insistem mais ainda na intimidade conjugal (Sociologia e sociedades, v. 35, n. 2, p. 79-86, 2003). Quando a mulher sente que não pode mais respirar, que está apagada, negada, descartada (segundo seus próprios termos), ela pede a separação ou o divórcio. Para ela, pelo menos, o nível de reconhecimento pessoal - mais comumente codificado sob o termo geral do amor que lhe traz seu parceiro - é o critério dominante da avaliação da relação. Para os homens, o conforto proporcionado pelo trabalho doméstico da mulher entra na equação. Eles podem buscar fora as satisfações sexuais. Os modelos masculino e feminino diferem, o primeiro é levado mais a se emparedar, a compartimentar, enquanto que o segundo possui uma demanda mais total, mais global. Nesse nível, não é evidente que mesmo a homogamia garanta a harmonia das exigências segundo o gênero. 0 artigo de Berger e Kellner permite compreender as razões da manutenção do atrativo da forma casal, pelo menos no ideal: é o espaço em que a individualização entendida como valorização de si mesmo pode ser desconectada, por um lado, de outras modalidades do individualismo contemporâneo, como a da competição.

A relação pais-criança conheceu uma transformação paralela, com grau de complexidade suplementar. Na realidade, a mãe e o pai devem dar atenção a seu filho, ajudá-lo a desenvolver sua individualidade, sua originalidade (seguindo os novos preceitos da psicologia), procurando enquadrá-lo para que ele possa ter o máximo de sucesso nos estudos. 0 amor parental é temperado pelas exigências da concorrência escolar. A tensão pode ser forte 
no momento da adolescência, quando o jovem insiste nas suas necessidades de expressão pessoal, reivindicando um mundo pessoal, frequentemente bastante afastado das referências escolares, os pais inquietando-se com seu futuro, com os recursos de que ele poderá então dispor.

A última sequência do seminário era nomeada "individualismo e individualização" Mesmo que eu tenha permanecido "sociólogo da família”, sobretudo aos olhos do público, eu me defini progressivamente como "sociólogo do indivíduo", convencido de que assim dispunha de um bom ângulo de ponto de vista para me inteirar das transformações do casal, da família, da educação. Também fui ajudado por um ambiente estimulante, com a presença, dentro do Centro de Pesquisas sobre os Laços (Universidade Paris Descartes, Nova Sorbonne e CNRS), de Jean-Claude Kaufmann, Philippe Corcuff e Danilo Martuccelli que seguiam, cada um, também essa via.

A leitura de historiadores, filósofos e escritores me fez compreender a especificidade do indivíduo durante essa modernidade. Ela repousa sobre o princípio da crença na existência de uma identidade "oculta", de um "eu profundo" que não se confunde com os papéis sociais. 0 indivíduo individualizado só existe na tensão engendrada por esta dualidade. Para mim, é o enunciado de Montaigne no livro III dos Ensaios, capítulo 10 (1588), que melhor exprime o núcleo duro dessa representação: "0 prefeito e Montaigne sempre foram dois, com uma separação bem clara". A essa época, Michel de Montaigne era prefeito da cidade de Bordeaux. Ele não dá importância às pessoas que esquecem esta dualidade e que se atêm ao jogo social. "Chega de empoar o rosto, sem empoar o peito (o coração). Vejo que elas se transformam e se transubstanciam em tantas outras figuras e em novos seres sobrecarregados de cargos e que se protegem (se refestelam assumindo uma atitude satisfeita) até o fígado e os intestinos e arrastam suas funções até seus guarda-roupas... São de tal forma centrados em suas pessoas que, mesmo durante a digestão e quando vão ao banheiro, são imbuídos até de seu interior”. A distância entre as duas dimensões de toda identidade é necessária, só ela autoriza a volta reflexiva sobre si mesmo e a possibilidade de mudanças voluntárias. Pode-se nomear esta separação de princípio de não coincidência ("A sociologia do indivíduo e o princípio de não-coincidência”, in: Monique Hirschhorn, 0 individuo social, 2007, Presses Universitaires de Laval, p. 69-84), remetendo ao enunciado de Jean Paul Sartre em $O$ ser e o nada (Gallimard, 1943): “0 si mesmo representa, pois, uma distância ideal na imanência do sujeito com relação a ele mesmo, uma forma de não ser coincidência”.

Para compreender minha leitura de Montaigne, dou o exemplo de um homem que se casa hoje em dia: "O marido e eu somos dois, com uma separação bem clara”. A difusão progressiva deste modelo de indivíduo que se acelerou há alguns anos conduz a uma certa desvalorização dos "engajamentos" fortes. As pessoas casadas, assim como os "companheiros", desejam preservar um "si mesmo" que não seja confundido com o seu status matrimonial. Montaigne havia antecipado essa distância: "Eu não sei me engajar tão profunda e inteiramente" (Livro III, capítulo 10).

Poderemos observar a importância conferida ao status da separação em tal representação.

A separação não resulta de um fracasso, ela é a condição de possibilidade da existência do indivíduo individualizado que não se esquece do desdobramento de si mesmo. É nesta ótica que analisei sucessivamente, em Livres juntos, a maneira pela qual cada cônjuge tenta preservar o seu "quanto-a-si"; nos Les adonaissants, a maneira como os jovens afirmam dispor de uma identidade pessoal, não redutível à de sua filiação, tomando emprestado provisoriamente outros hábitos, os de sua geração (o que resulta num processo inacabado de individualização); em Separada, a maneira como as mulheres estimam que a separação na vida conjugal (no sentido de Montaigne ou de Livres juntos) é fraca demais, principalmente pelo fato de que seus cônjuges as 
reduzem ao papel de esposa e mãe. Para exprimi-lo à maneira de Montaigne, um bom número dessas mulheres poderia afirmar: "Para meu marido, para meu companheiro, a esposa ou companheira e eu mesma não somos duas".

Um mal entendido deve ser evitado na leitura do enunciado comentado anteriormente. 0 autor dos Ensaios aceitou ser prefeito. 0 individualismo assim elaborado não consiste em recusar os papéis sociais, ele prega sobre um “quarto interior", para retomar um termo dos debates filosóficos, nos qual o indivíduo pode se retirar (cf. Jean-Louis Chrétien, O espaço interior, Minuit, 2014), deixando provisoriamente seus hábitos sociais, se desejar fazer um balanço de si mesmo. Trata-se de uma das grandes diferenças com a figura do renunciante na Índia (como analisa Louis Dumont, em seus Ensaios sobre o individualismo, Le Seuil, 1983). 0 indivíduo contemporâneo está "no mundo", passou da "aposentadoria” ao "afastamento".

Trabalhar a partir de longas conversas é necessário se desejamos compreender como a mulher e o homem vivem este afastamento, esta distância interior. Por exemplo, como apreender a separação ou o divórcio, se não ouvimos a maneira como a mulher ou o homem relata a distância entre o si mesmo que cada um reivindica e a identidade que seu cônjuge lhe atribui? (Sobre este primado da conversa, cf. Danilo Martuccelli, François de Singly, As sociologias do indivíduo, A. Collin, 2009). A sociologia do indivíduo valoriza a consciência dos indivíduos, o que não significa negar zonas de não consciência e mesmo de inconsciente, pois não é no interior da pessoa que ela se constrói como "indivíduo individualizado", é pela reflexividade que ela opera, pelo menos de tempos em tempos. 0 impensado da consciência em Bernard Lahire o leva a propor um modelo de indivíduo que desdobra suas diferentes socializações de acordo com as circunstâncias: o indivíduo é sacudido em função das interações, não tem poder sobre a maneira como se torna ele-mesmo. 0 modelo de indivíduo que me serve para socializar o mundo social é dotado de uma consciência que contém uma certa representação de si mesmo, servindo-lhe para julgar se lhe é suportável o afastamento entre o si mesmo que reivindica e os papéis sociais (cf. "A sociologia, forma particular de consciência", in: Bernard Lahire, Para que serve a sociologia? A Descoberta, 2004, p. 13-42).

Sublinhemos o ultimo termo do enunciado de Montaigne: "de uma separação bem clara”. Uma das dificuldades da construção da identidade reside, ao contrário, no fato de que a fronteira nem sempre é bem traçada! Quando as mulheres nos cursos de amor nos séculos XII e XIII julgavam que era impossível amar seu marido, a separação existia claramente. “'Esposa' e 'Eu' somos duas, uma separação bem clara”, esta era a reivindicação dessas mulheres, bem antes que Montaigne a declarasse. A mulher, enquanto "filha de" era reconhecida pelo casamento e, portanto, por seu marido, e enquanto pessoa única, era louvada pelo trovador amoroso. Estas duas funções eram realizadas por duas pessoas diferentes. Mas, progressivamente, o casamento fundiu-se ao amor, eliminando a separação entre o marido e o apaixonado.

Examinando minha situação pessoal: sou sociólogo e não existiria nenhuma relação entre esta cena sociológica em que atuo, retomando a metáfora de Erving Goffman, e o que penso ser minha identidade pessoal? Não acredito. A fronteira é porosa: ao investir nas pesquisas ultrapassando o que é solicitado, ao mesmo tempo eu me engajo pessoalmente e há efeitos teóricos que descubro sobre minha existência, sobre minha maneira de pensar e de ver o mundo. É por isto que a própria noção de separação clara dá uma imagem errada da fronteira entre a identidade social e a identidade pessoal.

No programa desse conjunto de seminários é apresentado, como epígrafe, o seguinte trecho de autoria de Jean-Paul Sartre (Critique de la raison dialectique, 1960): "Valéry é um intelectual pequeno burguês, sem dúvida. Mas nem todo intelectual pequeno burguês é Valéry. A insuficiência heurística do marxismo 
[sociologia] contemporâneo está contida nestas duas frases". Essa passagem parece traduzir algumas das inquietações que cercam os estudos sobre do tema da construção identitária. Como explicar a singularidade de Paul Valéry? Como essa questão pode ser respondida pela sociologia do indivíduo e, em particular, pela perspectiva da sociologia relacional?

Não estou certo de que a frase de Sartre seja totalmente justa. Até que ponto a sociologia do indivíduo tem por ambição explicar Valéry? Pierre Bourdieu, em Flaubert As regras da arte (Seuil, 1992) e em seguida em Manet (Seuil, 2013), e Bernard Lahire, com seu Kafka (La Decouverte, 2010), quiseram chegar até lá, depois do Mozart, de Norbert Elias. Mas estas pesquisas se assemelham mais a estudos de casos. Antes de tudo, seus autores sonham demonstrar que a força de seu quadro teórico pode chegar até a explicar tal ou qual indivíduo. Combinando as socializações múltiplas de um indivíduo e os efeitos de posição no campo da criação, eles esperam assinalar a ligação existente entre as propriedades sociais do autor e a originalidade de seu trabalho. A propósito de seu Flaubert, Bourdieu comenta: o assunto da obra é, pois, um habitus em relação com um posto, isto é, com um "campo" (Questões de sociologia, Minuit,1980, p. 212). E conclui: "Tendo assim construído o posto, isto é, a posição de Flaubert na divisão do trabalho literário [...] podemos nos voltar às condições sociais de produção do habitus e nos perguntar quem devia ser Flaubert para ocupar e produzir (inseparavelmente) o posto 'arte pela arte' e criar a posição de Flaubert. Podemos tentar determinar quais são os traços pertinentes das condições sociais de produção de Gustave [...] que permitam compreender o que tenha podido manter e produzir o posto de Flaubert" (p. 213-214). Eu não penso que essa resposta de Bourdieu corresponda ao que desejava Sartre a propósito de Valéry. 0 estilo de Flaubert é dedutível apenas dessas condições sociais? Demonstrar que o contexto define os recursos para coagir, em parte, as estratégias, não implica que toda a força desse autor derive disto. Encontramos o mesmo gênero de extrapolação na escolha do cônjuge: a mulher ou o homem escolhe o seu parceiro não independentemente de seus próprios recursos sociais. Isto não regula a totalidade da eleição pessoal. Há frequentemente várias pessoas possiveis que correspondem às pressões sociais. Resta uma margem de jogo que inscreve essa escolha em um processus de individualização.

Lutar contra a redução identitária que a sociologia produz quando ela limita a identidade de um indivíduo a alguns pertencimentos sociais (classe, gênero, geração etc.), acrescentando novidades "variáveis" à análise, como a do estudo do campo no qual a pessoa ocupa uma posição e como a da natureza das obras, não é suficiente para definir o indivíduo em sua dualidade identitária. "A problemática existencial para designar o conjunto de elementos ligados à situação social de um autor e que se impõem a ele" (grifo de FdS, Lahire, p. 81), esboçada pelo sociólogo, por mais interessante que seja, deveria incluir uma teoria distinguindo os elementos conscientes e os não conscientes. 0 si mesmo de um indivíduo, criador ou não, se retomamos o tópico de Georges H. Mead, em $O$ espirito, o si mesmo e a sociedade (Presses Universitaires de France, 1963), compreende um "eu passivo" e um "eu ativo", instância da consciência no seio da qual o indivíduo toma certas decisões de atualizar ou não, por exemplo esse ou aquele elemento de suas socializações ou, ao contrário, de recusá-los. Isso demanda possuir uma teoria dos equilíbrios entre "eu passivo" e o "eu ativo", o que não existe no momento, pelo que eu sei, no mercado das ideias sociológicas.

É preciso lamentar que não se disponha de uma sociologia desse ou daquele indivíduo? Não penso assim. Em todo caso, não tenho por ambição relatar o que diz Valéry, ou qualquer outra pessoa. Procuro relatar as maneiras como as pessoas se individualizam e conseguem assim mesmo dizer "eu". Meu objeto preciso 
é o processo de individualização. Assim, o individualismo institucional, no momento da adolescência, tende a impor a norma de uma afirmação legítima de si mesmo (temos uma referência disso quando os pais nas entrevistas afirmam, em relação à orientação de seu filho: "ele é quem decide, não podemos fazê-lo em seu lugar"). Como essa norma é aplicada? Como o adolescente produz um arranjo com seus pais para construírem juntos o campo dos possiveis para ele? Segundo quais modalidades? (Esse é o tema de um trabalho em curso de Marion Valarcher sob minha orientação). 0 postulado é que não há tantas formas do processus de individualização quanto há indivíduos concretos. A ambição é, portanto, conseguir a cada vez, após ouvir longamente as pessoas envolvidas, elaborar uma tipologia das formas de construir um pedaço de seu mundo pessoal (por meio de macetes para chegar à sua religião por exemplo). A sociologia do indivíduo, assim entendida, propõe-se apreender como a injunção social de ser ele mesmo se transforma em práticas.

O tipo de individualismo que você preconiza procura ultrapassar as visões tradicionais marcadas pela ambivalência e tensões entre o universalismo (do sujeito cidadão abstrato criado pela modernidade) e o particularismo (o sujeito individual, internalizado em si mesmo), situando-o na perspectiva de um certo humanismo. Essa questão está relacionada intimamente com as definições do "individualismo abstrato" e o "concreto". Você poderia falar um pouco dessa tensão? Pois ela parece ser definidora para suas perspectivas.

\section{Quando Émile Durkheim defende} o individualismo no caso Dreyfus, em " 0 individualismo e os intelectuais" (Revue Bleue, 1898, 4. ed., tomo X, p. 7-13), ele separa o joio do trigo. 0 individualismo que defende é o do indivíduo esclarecido pelas luzes da razão, e o que condena é o egoísmo. 0 primeiro individualismo, "bem longe de fazer do interesse pessoal o objetivo da conduta, ele vê em tudo o que é motivação pessoal a própria fonte do mal. Segundo Kant, eu só estou certo de agir bem se os motivos que me determinam se ligam não às circunstâncias particulares em que me coloco, mas à minha qualidade de homem in abstracto. Inversamente, minha ação é má quando ela só se justifica logicamente pela minha situação de fortuna ou pela minha condição social, pelos meus interesses de classe ou de casta, pelas minhas paixões etc. É por isso que a conduta imoral se reconhece pelo fato de estar estreitamente ligada à individualidade do agente e não pode ser generalizada sem absurdo manifesto". Portanto, Durkheim defende uma concepção do indivíduo próxima do "individualismo latino" que deseja alcançar o universal segundo George Simmel, e condena a glorificação de um si mesmo único, próximo do "individualismo germânico" (" $O$ individualismo", Marsyas, 1917). Ele esquece de citar Michel de Montaigne, que tem outra definição do individualismo: "É preciso reservar um lugar só para nós, um lugar franco, no qual estabelecemos nossa verdadeira liberdade, retiro principal e solidão".

A hierarquização deDurkheim corresponde à definição de um individualismo paradoxal que consiste em desqualificar as manifestações de um si mesmo singular. Na minha opinião, podemos aproximar essa hierarquização daquela que operava a psicologia do desenvolvimento moral antes de Carol Gilligan. Em Uma tão grande diferença (Flammarion, 1992), essa autora mostra que a abstração das regras morais para a conduta serve de referência mais para os rapazes, enquanto que as moças levam mais em conta a situação concreta, as circunstâncias particulares. 0 cuidado é uma forma de atenção por essa ou aquela pessoa, recusando o princípio abstrato de um tratamento, talvez igual, mas insensivel às diferenças individuais. 0 individualismo abstrato tem uma coloração masculina. Podemos ainda aproximar essa hierarquização daquela desenvolvida por Mead, na qual, num primeiro momento, a criança aprende a se comportar bem 
em relação às pessoas de referência, importantes, aos outros significativos, obedecendo, num segundo momento, às regras, porque são regras, porque elas são legitimadas em referência a um outro generalizado.

Levando em conta essas três dimensões (as duas formas do individualismo, os dois estágios do desenvolvimento moral, a passagem do outro significativo ao outro generalizado), percebemos que alguns autores propuseram uma visão muito parcial do indivíduo e do seu desenvolvimento. 0 individualismo como eu o concebo deve incluir essas duas dimensões, sem necessariamente hierarquizá-las. De outra forma, a clivagem entre razão e coração, no fundamento da justificativa da hierarquia dos gêneros no Ocidente, perdura ao preço de uma visão truncada (cf. Geneviève Fraisse, Os dois governos: a família e a cidade, Gallimard, 2000). 0 modelo do indivíduo deve romper não somente com o primado do personagem social, bem esboçado por Danilo Martuccelli em Gramática do indivíduo (Gallimard, 2002), como também com uma representação que privilegia o reino da razão. Inclusive na idade adulta, o homem ou a mulher necessitam tanto dos outros significativos que sustentem e validem sua construção, como do outro generalizado que lhe fornece as referências gerais e abstratas. Esta coexistência dos dois individualismos reclama regulamentos sutis, tal como percebemos, por exemplo, na "ética clínica", que define as regras não pelo alto, e valendo para todas as situações, mas por baixo e em função das situações concretas (numa elaboração coletiva).

Desde a metade dos anos 1960, desde a entrada na modernidade avançada ocidental, um acento maior é colocado sobre o desenvolvimento pessoal, sobre a busca de um si mesmo original. Assim, na França, uma psicanalista, François Dolto, teve grande influência na educação das crianças por meio de emissões radiofônicas cotidianas e muito ouvidas, sob o título de Quando a criança aparece (Seuil, tomos 1, 2 e 3, 1977). Ela pede aos pais para ficarem atentos a cada criança como se ela fosse única, se preocuparem menos com a imposição de regras morais do que com o respeito pela sua individualidade, falar com ela permanentemente para lhe explicar tudo o que lhe acontece. Em termos teóricos, ela desenha os contornos de uma educação à moda de "Berger e Kellner", no sentido em que o mundo em que a criança vive deve ser validado pela conversa com um outro significativo.

Não é certo que essa nova orientação teria encantado Durkheim que, desde suas lições sobre $A$ educação moral, em 1902-1903, denunciava a família na medida que a criança obedecia para dar prazer a sua mãe e não para se conformar com a regra geral. Essa proximidade relacional permitiu uma reconversão da família ao período seguinte, a partir do momento em que o individualismo institucional mudou de natureza, insistindo na autonomia da criança.

A articulação entre o individualismo abstrato e a valorização de um si mesmo pessoal não é definida em nenhum texto. Essa ausência preocupa certos especialistas, certos psicólogos que estimam que a criança se tornou "rei", contestando o bom fundamento das regras abstratas e que afirmando "é minha escolha" basta para tornar legítima tal decisão. Como conciliar as regras associadas ao viver junto, os esclarecimentos da razão com as exigências do desenvolvimento pessoal? Isto pede um esforço teórico, ainda inacabado, de invenção de uma nova representação da educação. De acordo com o primeiro modelo, defendido por Durkheim (e muitos outros, é bom lembrar que Durkheim na Sorbonne era encarregado pela República de escrever as boas maneiras republicanas para as crianças), a criança devia interiorizar o conjunto do social transmitido por seus educadores. Um segundo modelo, defendido entre outros por Dolto, desestabilizou o modelo da transmissão, para que a criança pudesse revelar sua natureza (cf. "As tensões normativas da modernidade", Educação e sociedades, 2003, 11, p. 11-33). Os pais ou o educador acompanham o jovem para ajudá-lo a valorizar os recursos pessoais depositados nele: "O desenvolvimento de uma 
criança se faz como se deve, o melhor possível, segundo a natureza que é a sua no começo [grifo de FdS], quando ela se sente amada pelos pais que se amam e quando há alegria no ar... Uma criança feliz, bem realizada, é aquela que se desenvolve como se deve, com suas particularidades que serão respeitadas" (Dolto, Quando a criança aparece). Esse modelo merece, na minha opinião, ser revisado, porque repousa sobre um postulado contestável: o da existência, desde o nascimento, de uma definição de si mesmo que bastaria descobrir e desenvolver, se as condições fossem boas ("revelação"). Ironicamente, podemos afırmar que François de Singly deveria tornar-se "sociólogo desde o seu nascimento"? Não acredito em tal destino.

0 terceiro modelo que assinalei em certos divórcios de mulheres se baseia na lógica da experiência. Essas mulheres alegam que precisam deixar seu companheiro, porque ele não é mais aquele que deve enfrentar com ela um novo caminho. Se $\mathrm{Na}$ estrada (de Jack Kerouac, 1957) permanece uma referência no imaginário ocidental, é porque ele insiste numa viagem formadora de si mesmo, inspirando-se na filosofia oriental (o Tao, o dào que significa via, caminho). Podemos reler Siddhartha, de Herman Hesse, publicado em 1922: "Para onde me conduzirá o caminho que sigo? Não é absurdo, esta estrada não segue em curvas, talvez nem mesmo em círculos? Que seja como ela quiser, eu a seguirei”. Nós nos afastamos da representação dominante associando, ainda no início do século XX na França, a razão e o progresso a uma estrada iluminada que não dava voltas. Não se trata aqui de aproximar as transformações da educação a outras mudanças sociais, mas sustentamos, pelo menos a título de hipótese, que existe uma certa coerência entre uma visão geral da sociedade (crise do progresso) e as representações do desenvolvimento pessoal durante a infância ou a idade adulta. 0 projeto de desenvolvimento pessoal não pode ser estabelecido a priori, ele é definido progressivamente, segundo Nicolas Bouvier, em $O$ uso do mundo (Droz, 1963), que afirma: "Acreditamos que vamos fazer uma viagem, mas é a viagem que nos faz, ou nos desfaz".

No contexto de seu trabalho sobre a individuação, você estudou adolescentes a fim de saber como eles podem se afirmar frente a seus pais e outros adultos. Você tem notado especialmente que, apoiando-se na cultura geracional, eles entram em forte tensão com a cultura herdada. Você pode precisar esta tensão?

0 modelo da transmissão, tanto do saber como da moral, é desestabilizado não só pelas razões que acabamos de enunciar (pela atenção às particularidades de cada criança), mas também pelo crescimento de uma cultura jovem que propõe, ao lado da cultura dos pais e da cultura escolar, outros produtos, outros saberes. Margaret Mead teve consciência disso, publicando O fosso das gerações (Denöel, 1971), no qual anunciava ao mesmo tempo o aparecimento de um aprendizado pelos jovens sem a mediação de pais ou professores e a própria inversão da relação pedagógica, na qual, algumas vezes, são as crianças que ensinam aos mais velhos. A escola, e mais ainda a escola francesa, marcada notadamente pelo curso magistral, foi enfraquecida. Os alunos estão presentes, mas a maioria em regime "presente-ausente", como afirma um dos membros da comissão nacional para a infância e a adolescência que dirigi (relatório dirigido ao Presidente da República: <http: //wwww.strategie.gouv.fr/ publications/um-developpement-complet-delenfant-de-ladolescent>). Eles ouvem um pouco os ensinamentos e procuram, ao mesmo tempo, com os novos suportes tecnológicos, ficar no seu mundo geracional. Por um lado, eles são alunos para agradar a seus pais, por outro, com seus colegas, estão abertos a tudo o que lhes é proposto por toda parte.

Ao contrário dos pais que admitem que sua filha ou seu filho se refugia no quarto ou fora, num mundo que lhes escapa, que seus filhos não são apenas "filho de" ou "filha 
de" mesmo dentro de casa, os professores, frequentemente, veem os alunos apenas como "alunos". Os jovens, sobretudo na adolescência, têm o sentimento de ser mal reconhecidos, e desertam silenciosamente. 0 conteúdo do saber escolar lhes parece ultrapassado. Para exprimi-lo esquematicamente, eles nutrem frequentemente a impressão de entrar na escola como se fosse num museu para ver e ouvir falar de coisas antigas, quanto muito do patrimônio. A crise da escola vem dessa forte distorção entre a valorização do diploma, chave universal do futuro profissional, e o tédio que os jovens experimentam. A pequena minoria que investe fortemente nessa instituição para ter acesso às classes preparatórias (pós-bac) ${ }^{5}$, tendo em vista as grandes escolas, esconde a floresta de alunos que esperam o recreio para encontrar os companheiros ou companheiras. Tendo os pais modificado sua atitude perante seus filhos, a escola (tendo em vista sua função central) não sabe, apesar de grandes esforços, como realizar o engajamento dos professores. Que lugar deve ter a escola: lugar de transmissão, numa sociedade que valoriza sobretudo a inovação? 0 mais surpreendente ainda é o fato de que a cultura que os sociólogos chamaram de "jovem" quando ela surgiu (nos anos 60 na França, por exemplo, na irradiação do programa Salut les copains) ${ }^{6}$ mudou de natureza. Ela se tornou geracional, os jovens, por um lado, conservando ao envelhecer uma parte desta cultura. Isso conduz a uma sociedade em que não existe guerra das idades, mas na qual persiste frequentemente uma coexistência pacífica entre as gerações. Podemos citar como exemplo a crise dos jornais cotidianos gerais (como o Le Monde), frequentemente explicada na passagem para o digital. Mas esquecemos

5- São classes especiais que preparam os alunos após o bacharelado para admissão nos cursos com seleção mais rigorosa das grandes escolas. Essas instituições, como a École Nationale d'Administration, a École Normale Supérieure, tem um funcionamento próprio, diferente do sistema universitário e abrangem todas as áreas do conhecimento.

6- Um dos primeiros programas radiofônicos destinado aos jovens franceses que surgiu no final dos anos 1950 e alcançou sucesso nos anos 1960. Posteriormente também se tornou uma revista. de fazer uma pergunta: "É possivel definir um mundo de informações intergeracional, uma cultura comum?"

Voltemos ao tema do individualismo. De alguma maneira você procura descolar sua percepção de individualismo do projeto de modernidade, colocando-o em um projeto humanista. Quais são as condições sociais e pessoais concretas para que esse individualismo se torne humanista de fato?

Para poder responder, devo primeiramente precisar a noção do individualismo ocidental tal como eu a reconstruí de acordo com minhas leituras. Para Durkheim, Simmel, Montaigne, Taylor, o conteúdo difere de acordo com cada autor e suas orientações sociais e políticas. Eu distingo quatro dimensões do individualismo, sem que haja uma ordem. A primeira é a definida por Immanuel Kant em $O$ que são as luzes? (1784) e defendida por Durkheim. 0 homem ou a mulher devem se tornar autônomos, libertando-se das autoridades superiores tradicionais, como Deus ou o Rei, ou ainda o pai (as três autoridades naturais do modelo contra-revolucionário, defendido por Louis de Bonald). Devemos sair, graças à razão, "fora do estado de tutela" (Kant). Nesse nível, o individualismo pode se traduzir pelo termo da emancipação. Na França, notadamente a escola republicana foi modelada de acordo com esse ideal: o professor esclarecido pelo seu saber, deve libertar as crianças das trevas (representadas no fim do século XIX pela Igreja Católica). No século XVIII, a Revolução Francesa é, por um lado, um movimento individualista. No domínio da família, ela institui o casamento civil e o divórcio por consentimento mútuo em 1792, tornando os cônjuges autônomos e responsáveis por seu casamento, que se torna então um contrato. Escondido no fundo de si mesmo, o indivíduo em certas condições pode estar sensível ao que a razão lhe recomenda. É o que se passa simbolicamente, por exemplo, na cabine no momento do voto. 0 indivíduo, livre 
de qualquer pressão, sozinho na cabine pode escolher seus representantes.

0 segundo aspecto remete a uma outra dimensão oculta: a identidade pessoal, o "eu" (no sentido de Mead, um "verdadeiro eu", para retomar uma expressão que muitas pessoas utilizam). É esse mergulho em si mesmo que tenta Montaigne em Os ensaios. A meu ver, as primeiras manifestações desse desdobramento entre as aparências sociais e a identidade pessoal acontecem com o amor cortês. A mulher casada deseja ser amada por suas qualidades pessoais por um amante, diferente do marido, que estima sua esposa segundo os critérios do valor social de sua linhagem. Enquanto que a primeira dimensão é legível nos textos de filosofia política, a segunda é muito mais legivel na literatura. Cito um trecho do Barbeiro de Sevilha (1775), de Beaumarchais: "Estou cansado das conquistas que o interesse, a conveniência ou a vaidade nos apresentam sem cessar. É tão doce ser amado por si mesmo" (grifo de FdS).

A terceira dimensão é aquela da humanidade comum. Neste caso, além das convenções sociais, temos todos uma identidade comum, reconhecida desde o seu preâmbulo, na Declaração Universal dos Direitos do Homem, de 1948: "Considerando que o reconhecimento da dignidade inerente a todos os membros da família humana e de seus direitos iguais e inalienáveis constitui o fundamento da liberdade, da justiça e da paz no mundo[...]". Se a autonomia está associada à primeira dimensão, a igualdade é apresentada nesta terceira. Cada pessoa, seja qual for sua história, seu comportamento ou sua posição social, pertence à "família humana". Vemos na passagem que a família, ao contrário da versão crítica sublinhada num outro momento da entrevista, não se inclina necessariamente para o lado conservador, porque ela cria a possibilidade da fraternidade entre todos. Enquanto que ao individualismo se associa, por automatismo, a solidão e o egoísmo, duas formas de negação de vínculo mais amplo, esta terceira dimensão salienta que o individualismo pode estar na fonte de relações entre os humanos e, também, entre duas pessoas (lógica do amor ou da amizade, própria à segunda dimensão), e ainda entre cidadãos, partilhando a mesma crença democrática.

A quarta dimensão é a da competição. Numa versão crítica de esquerda, o individualismo pode ser confundido com o neoliberalismo e o primado da lógica do mercado. Mas é uma redução dessa dimensão, pois no fundo de si mesmo, de cada um de nós, existem recursos que deveriam ser valorizados. Ora, os indivíduos são frequentemente julgados pelas suas aparências (a referência de seu bairro, seu nome...), indicando essa ou aquela religião, sua orientação sexual, seu gênero etc. 0 individualismo nessa dimensão pede que as pessoas sejam julgadas não em função de suas origens e de seus bens, mas em função de suas capacidades. É o princípio da igualdade das oportunidades contra os bens adquiridos por herança econômica ou cultural. Na França, a escola republicana traduziu isso pela prova anônima nos concursos, de tal forma que o trabalho de cada um fosse julgado por si mesmo e não segundo a imagem que o professor tinha do aluno e de sua identidade social. Mesmo que os mecanismos de reprodução dificultem a realização desse ideal, é colocado o princípio em nome do individualismo competitivo. Não é ilegítimo ganhar a corrida e ter, dessa forma, acesso aos recursos superiores (que podem ser considerados como "desigualdades justas”), sob a condição de que não haja trapaça, dopagem ou favoritismo. Apesar das críticas, a igualdade de oportunidades constitui um suporte para lutar contra as desigualdades justificadas por outros elementos de identidade que não sejam as capacidades pessoais. 0 feminismo igualitário se inscreve nessa tradição.

Mas vocês talvez se perguntem o que há de comum entre essas quatro dimensões para que elas possam, a meu ver, ser reagrupadas sob o mesmo termo. Todas repousam sobre uma representação da identidade circular em duas camadas: a primeira, mais exterior, é a dos papéis sociais, dos bens herdados; a segunda, a câmara interior que contém as quatro dimensões 
do indivíduo individualizado: a razão, a originalidade do meu "eu", minhas capacidades e minha humanidade comum. 0 individualismo e o processo central de individualização podem ser, pois, definidos como o mecanismo que torna legítima a crítica social das aparências sociais. 0 indivíduo só aparece em certos momentos de verdade, de nudez, como o fato de entregar uma prova anônima, de entrar numa cabine, de não ser julgado por alguém pelas aparências... Por esse motivo, escrevi um artigo - "0 ser desnudo. Ensaio sobre o individualismo contemporâneo" (in: Christian Bromber et al., Um corpo para si, PUF, p. 115-138) - mostrando como o despojamento pode constituir uma reconquista de si mesmo, difícil, abrindo para períodos de crise. Um romance de André Gide, O imoralista (1902), ilustra perfeitamente a operação pela qual um homem procura saber o que ele é verdadeiramente, esquecendo, ou tentando esquecer, seu saber e também sua cultura. "0 acúmulo de todos os conhecimentos em nosso espírito se esfacela como uma pintura, e por partes, põe a nu a própria carne, o ser autêntico que se escondia”. 0 homem se despoja daquilo que antes era importante para ele e que hoje parece secundário. Parece-nos que ele se esquece de que a nudez não é o objetivo final do individualismo. Na verdade, o individualismo não condena os hábitos sociais sob a dupla condição de que eles estejam de acordo com o que o indivíduo deseja ser, e que isso não o impeça de continuar a julgar além das aparências. Um exemplo histórico mais resolvido de desnudamento é o de Francisco de Assis, que recusou a herança de seu pai e por isso foi condenado. Em 1206, ele sai nu do tribunal, entregando suas roupas àquele que o criou, mas aceita uma vestimenta provisória que lhe oferece o bispo de Assis, antes de usar a roupa de pobre (Damien Boquet, "Escrever e representar o desnudamento de Francisco de Assis no século XIII", Margens mediterrâneas, 2008, 30, p. 3963). 0 indivíduo, para se emancipar, deve fazer um balanço de sua herança a fim de conservar o que lhe parece conforme à afırmação de si mesmo, como analiso em Uns com os outros (A. Colin, 2003, p. 27-74).

Não nos esqueçamos de que, para nos despojar, ainda que provisoriamente, é preciso ter hábitos sociais. Para que Montaigne experimentasse essa separação claramente, foi preciso que ele se tornasse prefeito! 0 herói de $O$ Imoralista critica o que aprendeu e isso pressupõe que teve a chance ter feito seus estudos: "Cheguei a desprezar em mim...estes estudos que primeiro eram toda a minha vida e, depois pareciam ter apenas uma ligação acidental e convencional comigo mesmo". Experimentar o sentimento de ser você mesmo, operando a crítica de suas aparências e de seus bens, é uma forma de luxo social para aqueles que dispõem de algo a mais que sua comum humanidade.

É por isso que o individualismo só é progressista quando existe uma política não apenas de emancipação, como também de redistribuição de recursos, de tal forma que cada um possa ter os meios de realizar seu projeto social. Em "Socialismo e Liberdade", artigo de 1898, Jean Jaurès declara que "o socialismo é o individualismo lógico completo". 0 termo "completo" deve ser compreendido num primeiro sentido: "A pessoa humana não mais afirma somente sua dignidade, sua grandeza, em alguns exemplares de escolha ou em algumas classes de privilégio, ela o afirma em todos os seus indivíduos". 0 individualismo, em todas as suas dimensões, só é completo se for um projeto coletivo. Podemos entender o termo "completo" em um segundo sentido: o individualismo não se corta em fatias. Não podemos conservar exatamente a dimensão da competição e nos submeter à lógica do mercado. Na relação já citada, eu retomo a noção de "completo", aplicando-a ao desenvolvimento da pessoa, criança ou adulto. É a reunião das quatro dimensões do indivíduo individualizado que fixa o horizonte: a razão e a igualdade de oportunidades não são sufıcientes para definir o individualismo, embora Émile Durkheim se apoiasse somente nessas duas dimensões. A expressão de sua originalidade e a dignidade de cada um são também indispensáveis. 
0 desenvolvimento completo do indivíduo e do individualismo pede, portanto, um equilíbrio entre esses diferentes elementos. Essa ponderação não está definida, a meu ver, em nenhum texto. A divisão do trabalho entre os especialistas e as lógicas de mobilização política e ideológica produzem frequentemente uma visão mais parcial do individualismo. É sem dúvida desejável que a ponderação não seja codificada, porque senão ela será contrária ao próprio modelo de um processo de individualização. Um sentido, no entanto, deveria se impor explicitamente: a presença de todas as dimensões em sua própria definição e também na sua relação com o outro. 0 individualismo só é um humanismo quando se repousa no desenvolvimento completo de cada um ou cada uma (em referência ao título da conferência de Sartre, de 1945, "0 existencialismo é um humanismo"). A competição e o cuidado, a razão e os sentimentos, a igualdade das possibilidades e a igualdade dos lugares (para retomar o esquema proposto por François Dubet), a comum humanidade e a expressão pessoal. A conciliação - marcada por todos esses "es"- é estimada socialmente. É assim que, enquanto respondo a estas perguntas, aparecem, nos Jogos Olímpicos do Rio, comentários sobre a humanização de Michael Phelps. Imediatamente após ganhar sua vigésima medalha, ele beijou sua mãe, sua esposa e seu filho. 0 comentário foi: "0 colosso estava emocionado até às lágrimas”. Seus colegas de natação saúdam o fato de ele não ser apenas "uma máquina de ganhar". 0 interesse humanista do projeto individualista se opõe ao homem unidimensional (Herbert Marcuse, Minuit, 1968), ao homem mutilado denunciado por Karl Marx. Para ele, o indivíduo somente se desenvolveria em "cada uma de suas relações humanas com o mundo, ver, ouvir, provar, pensar, comtemplar, querer, agir, amar, em resumo, (em) todos os atos de sua individualidade" (Os manuscritos de 1844).

0 trabalho de individualização deve chegar, idealmente, a produzir certo equilíbrio entre as quatro dimensões de si mesmo. Esse último não se encontra facilmente. Ele precisa de regulagem para que o adolescente, por exemplo, possa ter consciência quando colocado diante da afırmação de si mesmo, a marcação da distância geracional, as exigências de uma formação e de uma validação de suas capacidades. Com a divisão do trabalho entre os gêneros, o pai foi levado, em nome do interesse familiar e também do seu próprio, a super investir no trabalho profissional, delegando a outros, como à esposa, as outras dimensões da vida familiar, notadamente o cuidado, as coisas do coração, que lhe pareciam secundárias. Já a lógica do neoliberalismo leva ao culto da performance (Alain Ehrenberg, Calmann-Lévy, 1991). E ela procura estender sua dominação sobre a totalidade da existência dos indivíduos que deveriam gerir, gerenciar sua existência como aprendem na empresa.

As lutas ideológicas, políticas, se passam entre os campos que defendem versões parciais do individualismo. Por exemplo, poderíamos dizer esquematicamente que alguns grupos mobilizados pela causa dos migrantes buscam apoio na ideia de comunidade humana, ou no "humanismo", enquanto que os grupos mobilizados pela hierarquia das universidades e pela manutenção das grandes escolas na França o fazem em nome da excelência individual. 0 que torna difícil a legibilidade desses debates, desses confrontos, é que os partidários da comunidade humana não se reconhecem no termo "individualismo", porque pensam que somente a lógica da competividade e do mercado determinam essa noção. Para mim, o individualismo só é um humanismo se, primeiramente e somente, incluir as quatro dimensões e se estiver inserido no quadro de políticas que criem as condições de acesso a essas quatro formas de reconhecimento para qualquer um.

De acordo com o que você explora no livro L'individualisme est un humanisme (Éditions de l'Aube, 2005), no contexto da segunda modernidade surgem novas formas 
de identidade (de gênero, sexo, familiar etc.) que definem a sociedade contemporânea, tornando as relações identitárias mais complexas e diversificadas (e, provavelmente, mais difíceis de serem estudadas!). Você poderia, em primeiro lugar, explicar por que prefere tratar com o termo "segunda modernidade" e não "pós-modernidade"? E, em seguida, quais as direções e caminhos de compreensão e análises dessas novas relações?

Tudo acontece naquilo que é considerado a "camada" das aparências sociais. Ora, o lugar do sexo e da orientação sexual tornou-se, sob a pressão dos movimentos sociais e de teorização, dependente dessa camada exterior, dos bens que possam estar envolvidos. 0 movimento e o pensamento queer, com Judith Butler e outros, podem ser interpretados na perspectiva do individualismo. É possível a cada um ou cada uma recusar a se deixar definir pelas aparências do sexo biológico ou da dominação heterossexual. A pessoa na sua dimensão mais pessoal não inclui obrigatoriamente (mesmo que possa também fazê-lo) esses dois elementos identificadores. É por essa razão, me parece, e não somente pelo fato da mobilização da federação LGTB (lésbicas, gays, bi e trans), que o monopólio da heterossexualidade foi perdido. Em nome de que o Estado interveria na formação de um casal, a não ser pelas condições do consentimento (idade ou casamento)? Hoje em dia o casamento por amor une dois indivíduos que desejam viver juntos e serem reconhecidos como casal. Historicamente a heterossexualidade, como condição (tão evidente que não era nomeada) tinha sentido quando a função central do casamento era a reprodução biológica e social legítima. A desestabilização do casamento, com a concubinagem e a união livre conduziu a abandonar essa função. Esse contrato matrimonial parte, mesmo sob o olhar público, de uma lógica antes de tudo privada. A abertura do casamento aos homossexuais traduz, portanto, além da igualdade entre os indivíduos, o primado da expressão pessoal, pelo menos na esfera privada. Por que o "eu te amo" oficializado não poderia ser pronunciado entre duas pessoas do mesmo sexo?

A retomada da discussão sobre as fronteiras bem estabelecidas entre os gêneros, e também entre as idades, desestabiliza as representações de uma identidade cujos contornos seriam fixos. Assim as pessoas que consultam os centros de ética clínica estimam que não existe idade para procriar. Por que, por exemplo, uma mulher depois de 45 anos não tem mais acesso à Assistência à Procriação Médica (AMP) na França? Esta complexidade também é aumentada por um segundo fator, a passagem de uma identidade revelada a uma identidade forjada pela experiência (como notamos acima). Se o caminho que a pessoa segue é o que subentende sua definição, então sua identidade conhece mais bifurcações com a baixa de estandardização do trabalho e da família (Ulrich Beck, A sociedade do risco, 2001). A experiência também cresce pelo uso de certos suportes como as representações teatrais que abrem novos territórios permitindo testar aquilo que podemos ser. Para evitar os riscos de explosão, ou de alienação de si mesmo, o indivíduo pode se narrar, e narrar ao outro o que ele fez e também o que fizeram dele ao longo do caminho. Somente uma retomada sistemática das identidades narrativas (tais como as descreve Paul Ricoeur em $O$ tempo narrado: tempo e narrativa, tomo III, Seuil, 1985) permitiria saber como hoje os indivíduos individualizados descrevem e julgam seu caminho, definindo-se a si mesmos. Seria preciso a aproximação dessas narrativas com as proposições de narrativas que constituem as séries, encenando a experiência das heroínas e dos heróis e a forma como eles e elas se narram.

Então por que optar por modernidade avançada, ou segunda modernidade, e não pela noção de pós-modernidade? 0 programa de emancipação do indivíduo, definido nos séculos precedentes, deu-se sob a primeira modernidade até os anos 1960, canalizado pelo que descreveu Peter Wagner em Liberdade 
e disciplina (Métailié, 1996), e restrita pela imposição de instituições fortes e pelos limites à emancipação (basta tomar a condição das mulheres para entender). Os anos 50 e 60, com a geração beat, as lutas contra as discriminações raciais, o movimento de liberação das mulheres, o reconhecimento dos direitos das crianças etc., vão autorizar novas formas de emancipação. Gosto de tomar como exemplo o caso do divórcio na França. Ele foi estabelecido na França pela Revolução Francesa, em 1792, e suprimido no início do século XIX. No fim do século XIX e início do século $\mathrm{XX}$, tratou-se de restabelecê-lo. Durkheim tomou posição contra, a fim de proteger os indivíduos contra um excesso de individualismo, alegando que eles seriam mais felizes se mantidos por casamento estável ("O divórcio por consentimento mútuo", Revue Bleue, 1906, v. 44, n. 5, p. 549-554). Foi preciso esperar 1975 para que o divórcio por mútuo consentimento fosse de novo possível.

Sob a primeira modernidade, o individualismo foi muito limitado, notadamente pelo fato da repressão das expressões pessoais, do domínio de si mesmo, do próprio corpo (interdição da contracepção até 1967 e do aborto até 1975). Para ficar na questão do divórcio, em 2004 o Parlamento votou uma nova modalidade: "o divórcio pela alteração definitiva do laço conjugal”, pedido eventualmente somente por um dos cônjuges. Entendido na sua larga aceitação (com as quatro dimensões) o individualismo completo permanece a linha do horizonte de espera de muitas pessoas e de grupos através do mundo.

No livro Sociologia da família
contemporânea (um de seus textos
traduzidos para o português), você analisa a
individualização das relações familiares. A
aceitação do divórcio, o declínio da instituição
do casamento e a baixa taxa de fecundidade
levou ao nascimento de novos modelos
familiares. E, no seu trabalho, você chama atenção
particularmente para a dimensão relacional da
família, com a noção de outros significativos. É

por isso que você diz que no Ocidente, ao menos, a família - apesar das críticas legitimas dirigidas a essa instituição - desempenha um papel específico que pode ser positivo no processo de individualização. Você também pode esclarecer como essa função é exercida?

A qualidade relacional privilegiada nas relações conjugais, associada a um certo humor anti-institucional, leva a uma instabilidade da vida a dois, sem chegar a "um amor líquido", segundo a expressão de Zygmunt Bauman (Rouergue, 2006). Não é verdade que o efêmero seja valorizado no domínio afetivo. A maioria dos adultos conhece mais de uma vida conjugal, mas eles não trocam de parceiros como trocam de celulares. A extensão da lógica do mercado que preocupa Eva Illouz, em Por que o amor dói (Seuil, 2012), não é tão grande, notadamente com a multiplicação dos sites de encontros. Por uma razão que é insuficientemente realçada, a saber, a necessidade de estabilidade. É preciso explicar, porque a metateoria de Peter Berger e Hans Kellner, da qual eu partilho, não é suficientemente explícita em seu texto: se o amparo de um próximo, de um outro significativo é quase indispensável, é porque se pressupõe que o indivíduo é frágil. Podemos mesmo lançar a hipótese de que esta vulnerabilidade é maior nas sociedades em que as instituições são menos fortes, a segurança profissional diminui. A mulher e o homem só podem viver bem se os outros ao seu redor validam o mundo onde vivem. 0 amor compreende duas dimensões que é preciso distinguir: o cônjuge deve trazer um reconhecimento total, algumas vezes embelezado, segundo Stendhal em Sobre o amor (1822), e uma validação atualizada do outro e do seu mundo. A segunda é também tão indispensável como a outra. As mulheres que pensam em se separar se queixam da indiferença do seu companheiro. Inversamente o próximo consolida o mundo de seu parceiro e, portanto, sua identidade. Essa estabilidade é relativa, ela se condiciona à reciprocidade da relação e à manutenção da primeira dimensão. 
0 desenvolvimento das famílias monoparentais e das famílias recompostas não trai obrigatoriamente a existência de "novos modelos", entendidos no sentido de ideal. A maior parte de mulheres e homens querem viver com um próximo, sob a condição de que este lhes traga as satisfações desejadas em termos de reconhecimento e de validação. Os cônjuges que não se divorciam não têm um modelo diferente daqueles que se separam (exceto a ligação com a religião que autoriza mais ou menos o divórcio). Uns e outros têm uma relação comparável da relação conjugal. 0 crescimento da exigência relacional teve por efeito paradoxal tornar mais instável a união conjugal, sem desvalorizar, por isso, a necessidade do outro significativo. Nos casais homossexuais, essas duas dimensões podem existir da mesma forma que nos casais heterossexuais. Talvez, como subentende Anthony Giddens, nos casais homossexuais a exclusividade sexual conta menos que nos casais heterossexuais. Mas nada lhes proíbe inventar novas formas de reconhecimento e validação dissociando do modelo de fidelidade sexual.

Na relação entre pais e filho, (vimos com Françoise Dolto e sua demanda por um "banho de palavras" educativo desde o nascimento), os pais tornam-se também um outro significativo, trabalho que não pode delegar a outras pessoas. Os pais procuram exercer essa função favorizando a palavra durante as refeições (estamos longe do silêncio imposto à mesa aos meus irmãos mais velhos). 0 rito da leitura à noite antes do sono da criança participa dessa cultura da troca. Uma socióloga da leitura, Christine Destrez, num texto cheio de humor conta como não é sempre tão fácil de se submeter. <https://google.fr/sear ch? $\mathrm{q}=\mathrm{la}+$ mauvais+conscience $+\mathrm{de}+\mathrm{la}+$ sociologu $\mathrm{e}+$ de+la+lecturectie $=$ utf-8ctclient=firefox-b\&tgfe $\mathrm{rd}=\mathrm{crCtei}=\mathrm{uOKsV8uXBsbEaOaymagH}>$.

No entanto, a criança, ao crescer, para obedecer à injunção da autonomia e da independência, leva os pais a se descompromissarem relativamente. Eles devem permanecer o outro significativo parcialmente, senão aumentando demais a zona de validação, correm o risco de chegar a um controle demasiado da vida de seu filho. E quando os filhos se tornam adultos, eles é que comandam o jogo da validação manifestando o que querem de sua existência. Para que a conivência se estabeleça, devem ser encontrados terrenos de troca mútua.

0 processus de individualização requer dois elementos sob tensão. Por um lado, o próximo deve trazer a segurança, validar o mundo pessoal e reconhecer seu cônjuge e seu filho. Por outro lado, ele deve também respeitar o jardim secreto, "os territórios pessoais" (no sentido de Goffman), que não serão abertos. Uma das questões que me coloco ao observar, seguindo Christophe Giraud, o modo como jovens casais vivem hoje em dia é até onde o cônjuge, heterossexual ou homossexual, é e será "o outro significativo por excelência”. Berger e Kellner designam assim a pessoa que valida quase tudo, inclusive os outros validadores: "as definições da realidade de cada parceiro devem ser constantemente relacionadas com as definições do outro. 0 outro está presente em quase todos os horizontes da conduta cotidiana (grifo de B. e K.). Talvez deva-se esperar que o cônjuge permaneça uma figura importante, porém partilhando-a com outros. Eu observo desde alguns anos, nas entrevistas, a força da amizade e dos laços amigáveis pessoais, não conjugalizados durante a vida conjugal. Quase a metade dos casais entre 25 e quarenta anos afirmam estar de acordo com este ditame: "um cônjuge passa, os amigos ficam”. Se essa visão se difunde, o casal se manterá numa versão mais leve (fazendo uma analogia com os produtos alimentares). A diversidade dos "modelos" de referência diz respeito, antes de tudo, à maneira como a vida do casal é concebida: uns dando maior importância à vida comunitária e à validação conjugal, outros vivendo sob um registro em que "livres" é mais importante que "em conjunto" (cf. meu texto "Sobre a conversa conjugal”, in: Samuel Lespatier, $A$ incomunicação, NRS, 2013, p. 49-63).

$\mathrm{Na}$ minha perspectiva, o futuro da vida privada vai se fazer em torno dos outros 
significativos. Observamos em uma pesquisa que começo a desenvolver, que o animal doméstico (e por que não o robô?) passa a ser visto como um ser muito próximo, um novo membro da família. 0 interessante da palavra "família" é que as mudanças não afetam seu uso. Na França, a família dos anos 2015 não se parece com aquela dos anos 1935, mas, mesmo que isso desagrade aos nostálgicos, ela renasce como uma fênix.

Você tem uma grande experiência como professor universitário, investigador e formador de novos pesquisadores. No Brasil e em várias partes do mundo, o ensino superior e os programas de pósgraduação estão passando, hoje, por grandes transformações. Como avalia o mundo acadêmico contemporâneo, marcado pela competitividade, pela pressa, por pressões de toda ordem como, por exemplo, pela necessidade publicar muito, de conseguir fontes de financiamento etc.? Que conselhos daria para um jovem pesquisador? Está animado com as perspectivas futuras?

Eu passei da Universidade de Nantes (1972-1985) à Universidade de Rennes II (1985-1990) e, enfım, à Universidade de Paris Descartes (desde 1990). Portanto, eu ensino sociologia há mais de quarenta anos. Isso me dá uma certa experiência. Eu orientei um certo número de teses, umas duas dezenas de "meus" doutores tornaram-se professores e professoras, pesquisadoras ou pesquisadores. Na Faculdade de Ciências Humanas e Sociais da Sorbonne, criei em 2000, com alguns colegas, o Centro de Pesquisas sobre as relações sociais (Cerlis, associado ao CNRS), que dirigi durante mais de doze anos. Um outro componente de meu trabalho, desde os anos 1990, é a atividade editorial: dirigi coleções pedagógicas, ensaios e de pesquisas, primeiramente na editora Nathan e depois na Armand Colin e Dunod. Também exerci responsabilidades administrativas, como presidente da comissão nacional da pesquisa científıca da seção sociologia no CNRS e como membro do Comitê Nacional das Universidades, que gerencia as qualificações que permitem o acesso às carreiras de professor e pesquisador. E também publiquei dezenas de artigos e livros sobre minhas pesquisas (frequentemente executadas com a ajuda de meus alunos).

Assisti, portanto, a mudanças no ofício de professor-pesquisador, paralelas àquelas verificadas na organização nacional da pesquisa. 0 modelo proposto é evidentemente mais "industrial", com um componente mais coletivo. Quando cheguei à Sorbonne, quase cada professor tinha seu laboratório, do qual ele era frequentemente o único membro permanente, com os seus doutorandos. Hoje em dia, o Cerlis, por exemplo, compreende uns cinquenta membros permanentes. Os financiamentos da pesquisa, pela mediação da Agência Nacional da Pesquisa ou agências europeias, se concentram nos projetos associando várias equipes. 0 pesquisador isolado não tem mais centralidade e financiamento. Isso se traduz igualmente pelas incitações vindas das autoridades administrativas da pesquisa para publicar artigos, em detrimento do livro original. Antes, o livro remetia à obra de uma pessoa. Hoje, nas avaliações, um livro não conta mais que um artigo publicado em uma revista indexada internacionalmente, alinhando-se àquilo que já é praticado nas ciências chamadas duras. 0 que pensar dessas mudanças nas ciências sociais?

Há o risco de que a problemática teórica dos objetos de pesquisa seja negligenciada. Pelo menos a título pessoal, o prazer que usufruo com meu trabalho vem da transformação da questão social em questão sociológica, conforme o que prega $O$ ofício de sociólogo. Se "o ponto de vista constrói o objeto" (Bachelard), então o domínio das metodologias não basta para produzir a boa sociologia. A leitura das obras permanece decisiva para alimentar o questionamento. Para retomar uma expressão de Passeron, o trabalho de pesquisa requer "um espaço mental" (0 espaço mental da enquete, Enquête, 1995, p. 13-42). Esse espaço deve ser preservado 
na passagem de uma cidade "artista" a uma cidade "industrial", se usarmos a linguagem de Luc Boltanski e Laurent Thévenot, em Sobre a justificativa (Gallimard, 1991), para relatar as mudanças que se operam. Meu único conselho é preservar as condições sociais da inspiração que só chegam pela leitura de obras sociológicas, filosóficas e históricas, o que requer tempo que nem sempre está disponível, com a diminuição dos prazos de entrega das pesquisas.

Entretanto, é preciso se perguntar até onde as obras importantes no período precedente eram estritamente pessoais? Escrevi um documento mostrando como "Bourdieu" é "o nome de um esforço coletivo", associando dezenas de pesquisadores (A Revista Literária, n. 368, 1988, p. 39-44). Já havia, portanto, "sociólogos empresários", à maneira como Durkheim geria seu grupo de colaboradores, notadamente pela da publicação de $O$ Ano Sociológico (cf. Philippe Besnard, "A formação da equipe de O Ano Sociológico", Revista Francesa de Sociologia, v. 20, n. 1, 1979, p. 7-31). Somos talvez vítimas, na sociologia como na arte, da representação do artista isolado, maldito! Atrás dessas imagens, sobretudo na escultura, existiam os ateliês. No início do século XX, Auguste Rodin tinha ao seu redor umas cinquenta pessoas que trabalhavam com e para ele (entre elas Camille Claudel). Hoje o artista cuja cotação é a mais elevada no mercado é Jeff Koons. Em Chelsea, Nova Iorque, ele dirige uma centena de pessoas que realizam com minúcia os desenhos e as ideias do mestre. É tal o tamanho de certas exposições, que elas pedem uma mobilização de numerosos colaboradores. Da mesma maneira, Takashi Murakami não pintou sozinho o grande afresco de mais de cem metros, "Os 500 Arhats", exposto no Mori Art Museum. Estes artistas retomam a tradição do ateliê, nos moldes da Renascença italiana.

Se a dimensão mais industrial na arte não é necessariamente sinal de um declínio, não há nenhuma razão para que, nas ciências sociais, o processo seja mais negativo. Com a condição de que, no entanto, a produção coletiva não seja uma justaposição de noções reunidas sem princípio teórico diretor, e, portanto, que isso não nos conduza ao "neoecletismo" de certas arquiteturas pós-modernas!

\section{Bibliografia do entrevistado}

\section{Livros}

DE SINGLY, François. Comment aider l'enfant à devenir lui-même? Paris: Armand Colin, 2009: Fayard, 2010.

DE SINGLY, François. Le lien familial en crise. Paris: Rue d'Ulm, 2007.

DE SINGLY, François. Le questionnaire. Paris: Nathan, 1992. (Coleção 128). Traduzido para o romeno.

DE SINGLY, François. Le Soi, le couple et la famille. Paris: Nathan, 1996. (Essais \& recherches). Traduzido para o português. DE SINGLY, François. Les adonaissants. Paris: Armand Colin, 2006: Fayard, 2007.

DE SINGLY, François. Les jeunes et la lecture. Les Dossiers Éducation et Formations, Paris, n. 24, 1993.

DE SINGLY, François. Les sociologies de l'individu. Paris: Armand Colin, 2009. (Coleção 128). 2. ed. 2012, com Danilo Martuccelli. DE SINGLY, François et al. Les uns avec les autres. Paris: Armand Colin, 2003. (Individu et société). Traduzido para o português. 
DE SINGLY, François. Libres ensemble. Paris: Nathan, 2000. (Essais \& recherches). Traduzido para 0 italiano, português e coreano. DE SINGLY, François. L'individualisme est un humanisme. La Tour-d'Aigues: L'Aube, 2005.

DE SINGLY, François. Lire à 12 ans. Paris: Nathan, 1989.

DE SINGLY, François. Parents salariés et petites maladies d'enfant. Paris: La Documentation Française, 1993.

DE SINGLY, François. Politiques de l'individualisme. Paris: Textuel, 2005. (La discorde).

DE SINGLY, François. Séparée. Paris: Armand Colin, 2011. (Individu et société).

DE SINGLY, François. Sociologie de la famille contemporaine. Paris: Nathan, 1993. (Coleção 128). Traduzido para o alemão, português, italiano, grego e tcheco.

DE SINGLY, François. Un corps pour soi. Paris: PUF, Paris, 2005, avec Christian Bomberger, Pascal Duret, Jean-Claude Kaufmann, David Le Breton, Georges Vigarello.

DE SINGLY, Franç̧ois; DE SINGLY, Camille. Habitat et relations familiales. Paris: du Plan Construction, 1998.

DE SINGLY, François; THÉLOT, Claude. Gens du privé, gens du public. Paris: Dunod, 1989.

DE SINGLY, François. Fortune et infortune de la femme mariée. Paris: PUF, 1987. (Economie et liberte). Traduzido para 0 italiano e para 0 inglês.

\section{Obras organizadas}

DE SINGLY, François (Org.). Enfants adultes: vers une égalité des statuts? Paris: Universalis, 2004.

DE SINGLY, François (Org.). Etre soi d'un âge à l'autre: famille et individualization. Paris: L'Harmattan, 2001. (Logiques sociales). DE SINGLY, François. La famille: l'état des savoirs. Paris: Découverte, 1991.

DE SINGLY, François (Org.). L'injustice ménagère, Paris: Armand Colin, 2007; Hachette, 2009.

DE SINGLY, François (Org.). Pour être soi: être soi parmi les autres, famille et individualization. Paris: L'Harmattan, 2001. (Logiques sociales).

DE SINGLY, François; CHAUDRON, Martine. Identité, lecture, écriture. Paris: Centre Georges Pompidou, 1993.

DE SINGLY, François; COMMAILLE, Jacques (Org.). La question familiale en Europe. Paris: L'Harmattan, 1996. (Logiques sociales).

DE SINGLY, François; CORCUFF, Philippe; LE BART, Christian. L'individu aujourd'hui. Débats sociologiques et contrepoints philosophiques. Rennes: Presses Universitaires de Rennes, 2010.

DE SINGLY, François; MARTIN, Olivier; GIRAUD, Christophe (Ed.). Nouveau manuel de sociologie. Paris: Armand Colin, 2010.

DE SINGLY, François; PEIXOTO, Clarice Ehlers; CICCHELLI, Vincenzo (Org.). Família e Individualização. Rio de Janeiro: FGV, 2000. Avec Clarice Ehlers Peixoto et Vincenzo Cicchelli.

DE SINGLY, François; SCHULTHEIS, Franz. Affaires de famille, affaires d'État. Paris: l'Est, 1991.

DE SINGLY, François et al. La famille en questions, Paris: Syros, 1996. 


\section{Coordenação de números especiais de revistas}

DE SINGLY, François. La famille: transformations récentes. Problèmes Politiques et Sociaux, n. 685, 1992.

DE SINGLY, François. Le moi conjugal. Dialogue, n. 102, 1988.

DE SINGLY, François; BERNIER, Léon. Familles et école. Lien Social et Politiques, n. 35, 1996.

DE SINGLY, François; COMMAILLE, Jacques. La politique familiale. Problèmes Politiques et sociaux, n. 761, 1996.

DE SINGLY, François; GAUTHIER, Madeleine. Voir les jeunes autrement. Lien Social et Politiques, n. 43, 2000.

DE SINGLY, François; MESURE, Sylvie (Ed.). Le lien familial. Comprendre, n. 2, 2001. 